\title{
Provedoras e co-provedoras: mulheres-cônjuge e mulheres-chefe de família sob a precarização do trabalho e o desemprego*
}

\author{
Lilia Montali ${ }^{\star *}$
}

\begin{abstract}
Tendo como referências, por um lado, as mudanças no mercado de trabalho a partir dos anos 90, que redefiniram o padrão de absorção da força de trabalho e, por outro, as alterações nos arranjos familiares de inserção associadas a estes processos e às transformações do papel da mulher na família e na sociedade, este artigo procura mostrar a especificidade dos perfis de inserção no mercado das mulheres-cônjuge e das mulheres-chefe de família, que são co-provedoras ou provedoras em seus núcleos familiares. Nos rearranjos familiares de inserção no mercado de trabalho, sob a precarização das relações de trabalho e o desemprego, cresce a importância da participação das cônjuges e das chefes de família no mercado, ao mesmo tempo em que passam a ter papel de destaque para a composição dos rendimentos familiares. Embora marcadas pelas ocupações precárias, quando comparadas ao conjunto dos componentes familiares, apenas as cônjuges e chefes femininas apresentaram taxas de participação e de ocupação com variação positiva entre 1990 e 2003. Destacase o segmento de cônjuges ocupadas, metade sob vinculações contratuais precárias, que apresentam menor redução na proporção de vinculações não precárias nesse período. São analisados também os perfis ocupacionais nos grupos familiares em que se inserem e comparadas as famílias das cônjuges e das chefes de família que trabalham e que não trabalham. A contribuição destas mulheres para a renda de seus núcleos familiares tem reduzido a queda da renda nestes domicílios e, certamente, atenuado o aumento do empobrecimento na Região Metropolitana de São Paulo.
\end{abstract}

Palavras-chave: Rearranjos familiares de inserção. Precarização do trabalho. Desemprego.

\section{Introdução}

Neste artigo são abordadas as mudanças na participação das mulheres-chefes de família e das cônjuges no mercado de trabalho, que ocorreram nas últimas décadas e, especialmente, a partir dos anos 90 , sob o processo de reestruturação das atividades econômicas e a precarização do trabalho na Região Metropolitana de São Paulo (RMSP).
Esta temática é tratada em continuidade à linha de investigação que temos desenvolvido nos últimos anos, referente à análise das relações entre as mudanças no mercado de trabalho, a partir dos anos 90 , que redefiniram o padrão de absorção da força de trabalho, e os arranjos familiares de inserção associados a estes processos e às transformações do papel da mulher na família e na sociedade. Neste artigo, pretende-se mostrar a especificidade dos

\footnotetext{
*Trabalho apresentado no XV Encontro Nacional de Estudos Populacionais, Abep, realizado em Caxambu-MG-Brasil, de 18 a 22 de setembro de 2006.
}

** Pesquisadora do Núcleo de Estudos de Políticas Públicas da Unicamp. 
perfis de inserção no mercado das mulheres-cônjuge e das mulheres-chefe de família, que são co-provedoras ou provedoras em seus núcleos familiares. ${ }^{1}$

Em artigos anteriores, foram apresentados os rearranjos familiares de inserção no mercado de trabalho articulados sob a precarização das relações de trabalho e o desemprego, evidenciando a crescente participação das cônjuges e das chefes de família no mercado (MONTALI, 2000 e 2004). Mais do que isso, mostrou-se que este fato é a novidade nos arranjos familiares de inserção no mercado de trabalho articulados como forma de enfrentar o desemprego de parte dos adultos da família e a queda nos rendimentos do trabalho impostos pelo desemprego recorrente e pela precarização do trabalho e como tentativa de manter a renda familiar.

Assim, além da mudança nos arranjos de inserção dos componentes da família, foi possível apreender a crescente participação das chefes femininas sem cônjuge e das mulheres-cônjuges na composição dos rendimentos familiares, justificando estudo mais detalhado. Dessa maneira, é aqui analisada a inserção das cônjuges e chefes femininas no mercado de trabalho, bem como seus impactos nos rearranjos familiares de inserção, na renda das famílias e na atenuação do empobrecimento.

São analisados também os perfis ocupacionais nos grupos familiares em que se inserem essas mulheres e investigadas, de forma comparativa, as famílias das cônjuges e das chefes que trabalham e das que não trabalham.

A base de dados utilizada nas análises longitudinais, para a Região Metropolitana de São Paulo, é a série da Pesquisa de Emprego e Desemprego, realizada pela Fundação Sistema Estadual de Análise de Dados - Seade e o Departamento Intersindical de Estatística e Estudos Socioeconômicos - Dieese, para o período 1985 a 2003.

\section{Os impactos diferenciados da precarização e do desemprego sobre a inserção dos componentes da família}

$\mathrm{Na}$ década de 90 , acentuaram-se as transformações da economia sob o processo de reestruturação produtiva e o baixo ritmo de crescimento, mudando o padrão de incorporação da força de trabalho na Região Metropolitana de São Paulo (principal centro industrial e financeiro do Brasil). Ocorreram redução dos postos de trabalho, aumento do desemprego e maiores restrições para absorção em trabalhos assalariados regulamentados. As alternativas de emprego não-regulamentado, temporário na maioria dos casos e como autônomo, implicam prejuízos da qualidade da inserção no mercado de trabalho e perda da proteção oferecida pelos direitos trabalhistas. Para os trabalhadores e suas famílias, a conseqüência mais evidente da precarização dos vínculos contratuais e da instabilidade no emprego é a queda do rendimento proveniente do trabalho e da renda familiar per capita, registrada pelas estatísticas oficiais.

Os efeitos da reestruturação produtiva e do novo padrão de incorporação da força de trabalho, no decorrer da década de 90, manifestam-se no interior das famílias, em rearranjos de inserção de seus componentes no mercado, que nem sempre possibilitam manter os rendimentos familiares em seus níveis anteriores.

Um dos pressupostos do estudo é que a relação família-trabalho se constrói a partir da articulação entre as esferas da produção e da reprodução, através da divisão sexual do trabalho (BARRÉRE-MAURISSON, 1992), e que a inserção dos componentes da família no mercado de trabalho e as mudanças observadas são definidas, por um lado, pelas características da organização das atividades econômicas e, por outro, pelos valores e padrões que

"Apresentam-se resultados dos Projetos "Família-trabalho, condições de vida e políticas sociais" e "Regiões Metropolitanas do
Estado de São Paulo: mudanças na relação família-trabalho sob a precarização do trabalho e as condições sociais nos anos 90", astado de São Paulo: mudanças na relação familia-trabalho so 
regem as relações familiares e, mais especificamente, as de gênero.

Assim, foi possível identificar padrões de inserção no mercado de trabalho fortemente marcados pelas posições familiares e de gênero, verificando-se que as mudanças nas atividades econômicas afetaram de maneira distinta as possibilidades de absorção dos componentes da família (MONTALI, 2004).

Compreender essa diferenciação é importante porque contribui para a explicação sobre os limites dos rearranjos familiares de inserção no mercado articulados para sobreviver ao desemprego e à instabilidade que se acentuaram a partir da década de 90 , pois constatou-se que estes rearranjos conseguem atenuar, porém não impedem, a queda do rendimento familiar per capita.

Isto porque, por um lado, como conseqüência da "desestruturação do mercado de trabalho" na Região Metropolitana de São Paulo, houve tendência de redução do rendimento dos ocupados em geral (POCHMANN, 2001; HOFFMANN e MENDONÇA, 2003), com especificidades nas distintas posições na família. Por outro lado, porque, relacionado à divisão sexual do trabalho, os componentes da família que apresentavam maior disponibilidade para o mercado de trabalho (chefes masculinos, filhos e filhas adultos) - evidenciada pelas taxas de participação e de ocupação mais elevadas - e que apresentavam também melhor qualidade de inserção - indicada por ocupações "regulamentadas" e protegidas pela legislação trabalhista - sofreram maior impacto durante o processo de reestruturação produtiva, que reduziu postos de trabalho assalariados regulamentados e elevou o desemprego. Os chefes masculinos e filhos(as) adultos sofreram profundo processo de precarização do trabalho a partir de 1990 (MONTALI, 2004).

Nesse mesmo período, as cônjuges e chefes femininas, que se caracterizam por padrão de inserção marcado por ocupações precárias, passaram a ter maior peso entre os ocupados da família. As possibilidades de expansão de sua inserção no mercado de trabalho são, principalmente, em ocupações precárias, tais como assalariadas sem carteira assinada, emprego doméstico, autônomas e trabalhadoras familiares, que oferecem baixos rendimentos.

Assim, a precarização do trabalho e o desemprego recorrente, na RMSP, contribuíram para diminuir as remunerações dos componentes familiares e provocar a queda do rendimento familiar per capita. Ainda que os rearranjos familiares de inserção no mercado não tenham conseguido impedir o empobrecimento, a pesquisa evidencia que a crescente participação das cônjuges e chefes femininas ocupadas, na composição da renda familiar, tem reduzido o impacto do empobrecimento de suas famílias, quando comparadas às famílias das nãoocupadas.

Entre as várias indicações apresentadas no decorrer deste artigo, destacamse duas que sintetizam a relevância da inserção das cônjuges e das chefes de família no mercado para reduzir os impactos da precarização do trabalho no empobrecimento das famílias na RMSP.

Em primeiro lugar, a análise da precarização do trabalho, considerando-se as posições na família e o gênero, revela que, entre o conjunto dos componentes familiares, apenas as cônjuges e as chefes apresentaram taxas de ocupação e de participação com variação positiva entre 1990 e 2003 (Gráfico 1).

Em segundo lugar, em que pese o fato de as cônjuges e chefes femininas serem caracterizadas por inserção em ocupações com vinculações contratuais predominantemente precárias, quando comparadas com os chefes masculinos e os filhos e filhas maiores de 18 anos, estas são, entre os compo-nentes familiares, as que menos sofreram redução na proporção de ocupados em postos de trabalho não-precários no período estudado (Gráfico 2).

A análise da PIA das cônjuges evidencia que a proporção de ocupadas, entre 1985 e 2003, cresceu 13 pontos percentuais (31\% em 1985, 35\% em 1990, 40,3\% em 1995 e 44\% em 2003) e cerca de 20\% estavam em ocupações não-precárias, a partir dos anos 90. Desde o inicio da série analisada até 1995, cerca da metade das cônjuges ocupadas encontrava-se em 


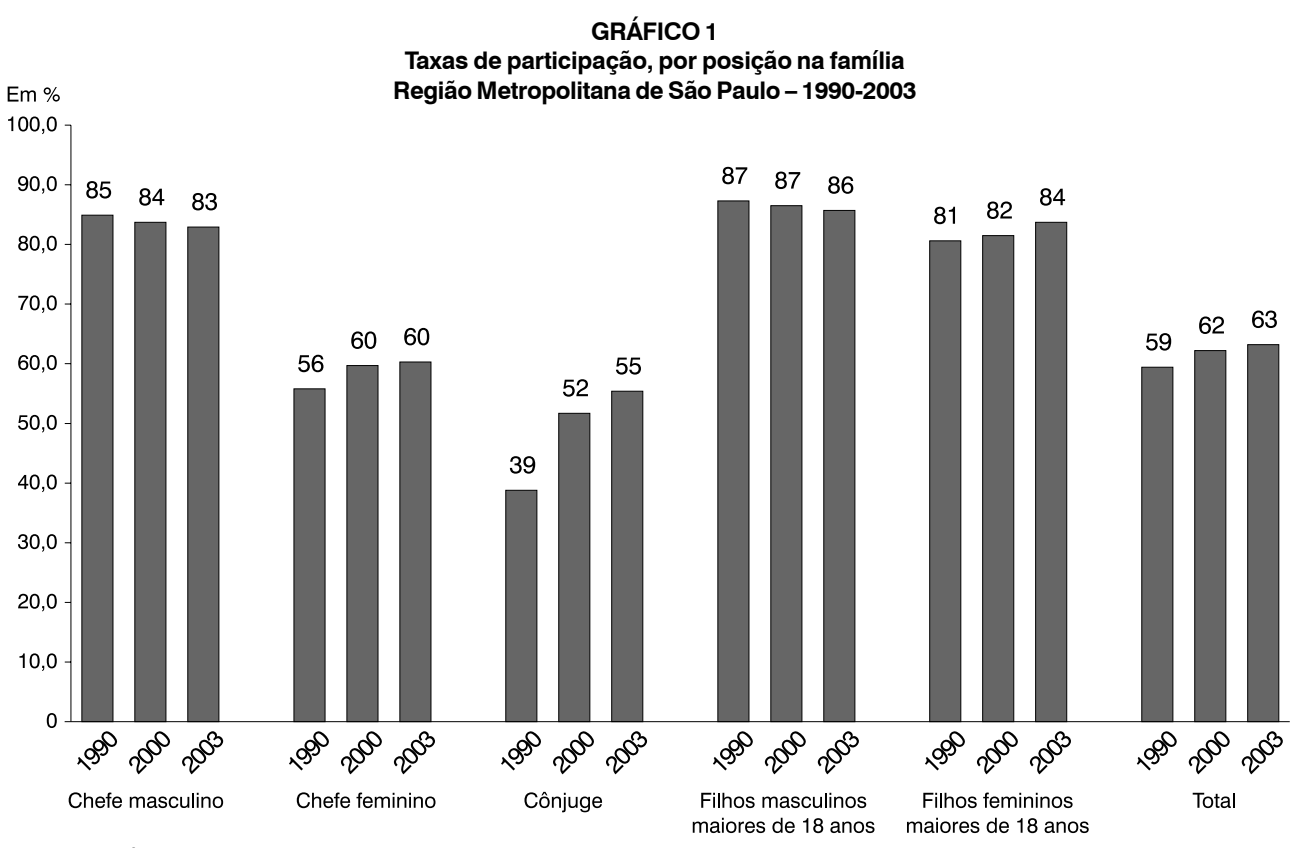

Fonte: Convênio Seade-Dieese. Pesquisa de Emprego e Desemprego - PED. Elaboração da autora.

GRÁFICO 2

Distribuição da PIA, por posição na família, segundo situação ocupacional e condição de precariedade dos postos de trabalho

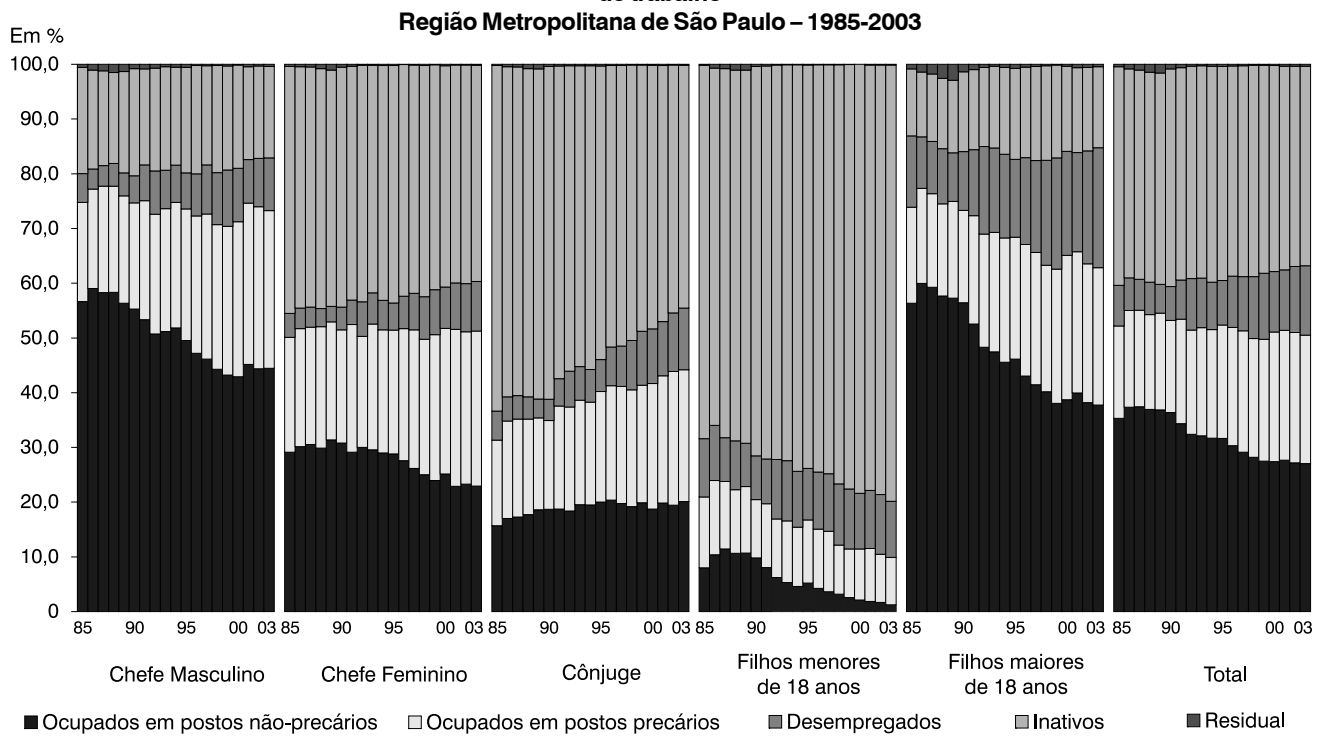

Fonte: Convênio Seade-Dieese. Pesquisa de Emprego e Desemprego - PED. Elaboração da autora.

inserções não-precárias. No entanto, o aumento na proporção de ocupadas, a partir de 1995, se deu predominantemente através da expansão das ocupações precárias: $20 \%$ em 1995, 23\% em 2000 e 24,5\% da PIA em 2002 e 2003, enquanto a 
proporção de ocupadas em postos nãoprecários se manteve, no período, em cerca de $20 \%$ (Gráfico 2).

Para as chefes de família, a análise da PIA mostra que cerca de $52 \%$ permaneciam ocupadas no período, sendo $31 \%$ inseridas em postos não-precários, em 1990. No decorrer da década 90 e inicio dos anos 2000 , houve queda na proporção de ocupações não-precárias dessas mulheres mais acentuada do que para as cônjuges ocupadas, com perda de 8 pontos percentuais entre 1990 e 2003, e correspondente aumento das inserções em ocupações precárias (Gráfico 2).

$\mathrm{Na}$ análise da presença das chefes femininas entre os ocupados, deve ser ressaltado que, se por um lado, cerca de $52 \%$ estavam ocupadas no período analisado, por outro, cresceu a proporção de famílias chefiadas por mulheres, entre 1985 e 2003, indicando o aumento absoluto de inserção destas no mercado de trabalho. Em 1985, cerca de $16 \%$ das famílias da Região Metropolitana de São Paulo eram nucleadas pela chefe feminina sem a presença de cônjuge, aumentando para mais de $20 \%$, em 1995, e para $23,8 \%$, em 2003. Cresceu também, entre as famílias da região metropolitana, a proporção daquelas nucleadas pela chefe feminina ocupada: em 1985, eram $8 \%$ do total das famílias e, em 2003, correspondiam a $12 \%$ (Tabela 1 ).

No caso das famílias nucleadas por casais, ocorre movimento inverso, ou seja, reduzem-se as proporções desse tipo de

TABELA 1

Distribuição das famílias, segundo tipologia e condição de ocupação das cônjuges e chefes femininas Região Metropolitana de São Paulo - 1985-2003

\begin{tabular}{|c|c|c|c|c|c|}
\hline Tipologia da família & 1985 & 1990 & 1995 & 2000 & 2003 \\
\hline Casal & 76,5 & 75,6 & 72,2 & 68,7 & 67,3 \\
\hline Com cônjuge ocupada & 23,9 & 26,2 & 28,7 & 28,0 & 29,1 \\
\hline Com cônjuge não-ocupada & 52,2 & 48,6 & 42,4 & 39,1 & 36,6 \\
\hline Casal sem filhos & 12,8 & 13,4 & 13,6 & 13,4 & 13,7 \\
\hline Com cônjuge ocupada & 4,6 & 5,1 & 5,2 & 5,5 & 5,9 \\
\hline Com cônjuge não-ocupada & 8,0 & 8,2 & 8,0 & 7,4 & 7,4 \\
\hline Casal com filhos & 63,7 & 62,2 & 58,6 & 55,3 & 53,6 \\
\hline Com cônjuge ocupada & 18,3 & 20,0 & 22,2 & 21,2 & 23,2 \\
\hline Com cônjuge não-ocupada & 42,6 & 38,8 & 32,8 & 30,0 & 29,2 \\
\hline Casal até 34 anos com filhos e/ou parentes & 31,4 & 28,3 & 24,2 & 21,4 & 20,2 \\
\hline Com cônjuge ocupada & 9,5 & 9,5 & 9,5 & 8,5 & 8,6 \\
\hline Com cônjuge não-ocupada & 21,8 & 18,5 & 14,4 & 12,6 & 11,2 \\
\hline Casal 35-49 anos com filhos e/ou parentes & 21,1 & 22,3 & 23,3 & 21,7 & 20,9 \\
\hline Com cônjuge ocupada & 7,4 & 8,8 & 10,9 & 10,5 & 10,7 \\
\hline Com cônjuge não-ocupada & 13,7 & 13,3 & 12,1 & 10,9 & 9,8 \\
\hline Casal de 50 anos e mais com filhos e/ou parentes & 8,6 & 8,5 & 8,2 & 8,8 & 9,2 \\
\hline Com cônjuge ocupada & 1,4 & 1,6 & 1,8 & 2,3 & 2,6 \\
\hline Com cônjuge não-ocupada & 7,2 & 6,9 & 6,4 & 6,4 & 6,5 \\
\hline Chefe feminina sem cônjuge & 15,9 & 16,7 & 19,6 & 22,0 & 23,8 \\
\hline Ocupada & 8,0 & 8,6 & 10,1 & 11,4 & 12,0 \\
\hline Não-ocupada & 7,9 & 8,0 & 9,6 & 10,6 & 11,8 \\
\hline Chefe feminina sem cônjuge com filhos e/ou parentes & 12,1 & 12,9 & 15,0 & 16,6 & 18,1 \\
\hline Ocupada & 6,4 & 7,1 & 8,1 & 9,0 & 9,5 \\
\hline Não-ocupada & 5,7 & 5,7 & 6,9 & 7,5 & 8,6 \\
\hline Chefe feminina sem cônjuge unipessoal & 3,8 & 3,9 & 4,6 & 5,4 & 5,7 \\
\hline Ocupada & 1,6 & 1,5 & 1,9 & 2,3 & 2,4 \\
\hline Não-ocupada & 2,2 & 2,3 & 2,7 & 3,1 & 3,3 \\
\hline Chefe masculino sem cônjuge & 7,6 & 7,6 & 8,1 & 9,2 & 8,8 \\
\hline Total (1) & 100,0 & 100,0 & 100,0 & 100,0 & 100,0 \\
\hline
\end{tabular}

Fonte: Convênio Seade-Dieese. Pesquisa de Emprego e Desemprego - PED. Elaboração da autora.

(1) O total por arranjos familiares inclui "não informados" e "residual" e a condição ocupacional inclui situações maldefinidas. 
família no total da Região Metropolitana de São Paulo, com decréscimo de 11 pontos percentuais, entre 1985 e 2003. Embora permaneçam como o arranjo predominante, estas famílias representavam 76\% em 1985 e $67 \%$ em 2003 (Tabela 1).

Apesar dessa queda e em movimento oposto, aumentou a proporção de famílias nucleadas por casal com cônjuge ocupada, em relação ao total das famílias da região metropolitana, passando de $24 \%$, em 1985 , para $26 \%$, em 1990 , e para $29 \%$, em 2003. Ao mesmo tempo, diminuiu fortemente a proporção de famílias com cônjuge nãoocupada, que representavam a metade das famílias da região metropolitana em 1985 (52\%), decrescendo para 48,6\%, em 1990, e para 36,6\%, em 2003 (Tabela 1).

\section{O trabalho das cônjuges e das chefes femininas: mudanças nos arranjos de inserção e efeitos na renda familiar}

A inserção das cônjuges e mães em atividades remuneradas é afetada pelas representações sociais das atribuições femininas, definidas a partir da tradicional divisão sexual do trabalho, que permanece como padrão ideal na sociedade, destinando o homem ao trabalho e a mulher às atividades voltadas para a família. Suas taxas de ocupação são mais baixas quando comparadas tanto às de outras mulheres em posições familiares diferentes, tais como filhas adultas e mulheres-chefes de família, como às taxas de ocupação de maridos e filhos adultos (MONTALI e LOPES, 2003). No entanto, na década de 90 , cresceu a participação das mulheres casadas e mães em atividades no mercado e de forma mais intensa em alguns tipos de família.

Dessa maneira, as taxas de ocupação e de participação, com variação positiva entre 1990 e 2003 para as chefes e cônjuges femininas, bem como as menores perdas de ocupações não-precárias na década de 90, por um lado, evidenciam a expressão dos impactos diferenciados da precarização do trabalho para os componentes familiares sob a mudança do padrão de absorção do mercado de trabalho nessa década e, por outro, sinalizam que a mobili- zação das mulheres com responsabilidade pela manutenção do núcleo familiar é reforçada pela mudança na sociedade na aceitação do novo papel da mulher como co-provedora. Esta interpretação corrobora uma das hipóteses deste trabalho, cujo suposto é que as situações de crise econômica propiciam mudanças na relação famíliatrabalho e nas relações de poder na família.

Alguns estudos recentes, ainda que apontando para a mesma direção de maior participação das cônjuges na provisão familiar, evidenciam as resistências a tais mudanças nas relações de poder internas à família. Embora presentes nas diversas situações sociais (ARAÚJO e SCALON, 2005), estas resistências têm se explicitado de forma mais clara nas famílias de baixa renda, nas quais, apesar das evidências na mudança do padrão de provisão, a autoridade masculina é reivindicada como prerrogativa, gerando conflitos, violência doméstica e alcoolismo masculino (OLIVEIRA, 2005; NASCIMENTO, 2005; MENDES, 2005).

A tendência de redução da participação do chefe entre os ocupados da família e de crescimento da importância dos demais componentes da família já começava a ser apontada pelos estudos sobre os anos 80 (JATOBÁ, 1990). Porém, só a partir de 1990 foi possível detectar o estabelecimento de um novo padrão familiar de inserção no mercado de trabalho, no qual, cada vez mais, a mulher-cônjuge assume o papel de co-provedora (MONTALI, 2004). Um exemplo dessa mudança é verificado na comparação entre o padrão de inserção familiar no início da década de 80 , período marcado pela crise econômica, e o observado no decorrer dos anos 90 e 2000. Naquele primeiro momento, os chefes de família representavam cerca de $45 \%$ dos ocupados na Região Metropolitana de São Paulo, a cônjuge $13,5 \%$ e os filhos $32 \%$. Com a agudização da crise, em 1983, observouse, como dinâmica de enfrentamento da redução do emprego do chefe masculino, aumento da participação dos filhos entre os ocupados $(36,4 \%)$ (MONTALI, 1995). No entanto, nos anos 90, alterou-se essa tendência, concomitante à acentuação do processo de reestruturação produtiva e ao 
aumento do desemprego. Identifica-se o estabelecimento de um novo padrão de arranjo familiar de inserção no mercado de trabalho, em que a participação dos chefes de família (masculinos e femininos) se mantém em torno de pouco menos que a metade dos ocupados e diminui, progressivamente, a participação dos filhos, mais especialmente a partir de 1992, crescendo a inserção da cônjuge entre os ocupados e os mantenedores da família (MONTALI, 2004). Assim, em 2003, os chefes (masculino e feminino) representavam cerca de $48 \%$ dos ocupados da família, os cônjuges $21 \%$, os filhos $25 \%$ e os outros parentes e não-parentes, em torno de $6 \%$. Nota-se, nas famílias nucleadas pelo casal, um maior partilhamento da responsabilidade pela provisão da família entre seus membros. Nestas, em 2003, as cônjuges compunham $28 \%$ dos ocupados da família, os chefes masculinos, $47 \%$ e os filhos, $21 \%$. No entanto, existem diferenças nas proporções dos componentes ocupados da família entre os diversos arranjos familiares, relacionadas com especificidades da composição familiar e momento do ciclo vital das famílias, como se verá.

Nas famílias nucleadas pela chefe feminina, a responsabilidade pela provisão da família é partilhada, principalmente, por ela, que representa $46 \%$ dos ocupados, e os filhos $(41,5 \%)$, com importante participação de parentes e não-parentes, representando cerca de $12 \%$ dos ocupados da família.

\section{Cônjuges: características da inserção familiar no mercado de trabalho e contri-buição para a provisão da família}

São observados dois momentos em que se acentua o crescimento da ocupação das cônjuges: o ano de 1991, marcado por elevado desemprego provocado pela reestruturação produtiva, que se intensificou em resposta à abrupta abertura da economia ao comércio internacional; e a partir de 1995, ano de expansão da economia, seguida por gradual queda e crise econômica em 1998 e 1999, quando o crescimento do PIB ficou abaixo de $1 \%$ e o desemprego recrudesceu, atingindo taxas antes não conhecidas nessa região metropolitana. ${ }^{2}$ Tanto o desemprego elevado como a continuidade da mobilização das cônjuges para o mercado se estenderam até o final do período analisado.

Assim, a partir de 1996, em cerca de $41 \%$ dos domicílios nucleados pelo casal, a cônjuge estava ocupada, chegando a 44\% em 2003 (Tabela 2). A tendência de aumento na proporção de cônjuges ocupadas, no decorrer dos anos 90 e 2000, ocorreu em todos os tipos de arranjos familiares nucleados pelo casal, ainda que com especificidades marcadas pelas características associadas à composição e ao ciclo de vida familiar.

A análise da evolução da proporção de cônjuges ocupadas, segundo tipo de arranjo familiar, deve considerar que, no período analisado, alteraram-se as proporções dos distintos arranjos familiares na Região Metropolitana de São Paulo, em decorrência tanto de alterações nos tipos de arranjo familiar (redução na proporção de famílias nucleadas por casal, aumento na de casais sem filhos e de famílias chefiadas por homem ou mulher sem a presença de cônju$\mathrm{ge}^{3}$ ) como de mudanças na estrutura etária, conseqüente do envelhecimento da população (Tabela 1). Tais fatos afetam a proporção das cônjuges ocupadas correspondentes a estes arranjos.

Examina-se, a seguir, a evolução das cônjuges ocupadas por tipo de arranjo familiar, construídos tendo por referência a presença de filhos e o ciclo vital familiar (Tabela 2). As famílias de casais de 50 anos e mais com filhos e/ou parentes, que apresentam a menor participação entre as famílias nucleadas por casais (Tabela 1), são também as que possuem menor proporção de cônjuges ocupadas, caracterizando-se pela etapa final do ciclo familiar vital, quando

${ }^{2}$ As taxas de desemprego oscilavam ao redor de $15 \%$ entre 1992 e 1996, exceto 1995. A partir de maio de 1997 recrudesce o desemprego na RMSP e define-se um patamar mais elevado das taxas anuais de desemprego (18,2\% em 1998; 19,3\% em 1999; $17,6 \%$ em 2000 e 2001; 19,9\% em 2003). Pesquisa de Emprego e Desemprego - Convênio Seade-Dieese.

${ }^{3}$ Este tema é tratado com maior detalhe em Montali (2003a). 
ainda residem filhos, em sua maioria adultos, com o casal. Em tendência ascendente, em 1985, 16\% das cônjuges dessas famílias eram ocupadas, passando para cerca de 20\%, de 1986 a 1992, para 22\% em 1995 e para $28 \%$ em 2003. O período de maior crescimento ocorreu a partir de 1995, acentuando-se desde os anos de maior desemprego no final da década de 90 . Em artigos anteriores, foi indicado o aumento do desemprego dos filhos adultos nesse período (MONTALI, 2003a e 2004).

Entre os arranjos familiares que concentram maiores proporções de famílias nucleadas pelo casal, estão aqueles formados por casal de até 34 anos com filhos e/ou parentes, que correspondem à fase inicial do ciclo de vida familiar, e por casal de 35 a 49 anos com filhos e/ou parentes, que correspondem à fase de expansão da família (Tabela 1).

$\mathrm{O}$ arranjo de casais de até 34 anos com filhos apresenta, comparativamente, menor proporção de cônjuges ocupadas: eram $30 \%$ em 1985 e passaram para cerca de $34 \%$ até 1991. A partir desse ano apresentaram taxas de ocupação mais elevadas, que oscilaram entre 37\% e 39\% até 1995 e ultrapassaram $40 \%$ a partir de 2000 , revelando o aumento do emprego da cônjuge jovem e, na maioria dos casos, com filhos pequenos (Tabela 2).

Nos arranjos familiares de casais de 35 a 49 com filhos e/ou parentes, a proporção de cônjuges ocupadas cresceu no período estudado, seguindo os momentos de inflexão referidos, ou seja, em 1985, 35,1\% das cônjuges dessas famílias eram ocupadas, de 1986 a 1990 essa proporção ficou em torno de $39 \%$, voltando a crescer a partir de $1991 \mathrm{e}$, em 1995, acentuou-se o crescimento e $47,5 \%$ das cônjuges eram ocupadas. Nos anos de desemprego mais elevado, a partir de 1998, aumentou progressivamente a taxa de ocupação das cônjuges, ultrapassando $50 \%$ a partir de 2001. Desde 1990, esse arranjo familiar apresenta as mais elevadas taxas de ocupação entre as cônjuges (Tabela 2). Em estudo anterior, evidenciou-se que, além da elevação da taxa de ocupação das cônjuges neste tipo de arranjo familiar, ocorreu redução da taxa de ocupação dos filhos, bem como de sua participação entre os ocupados da família (MONTALI, 2004).

TABELA 2

Distribuição das cônjuges, por arranjo familiar, segundo condição de ocupação Região Metropolitana de São Paulo - 1985-2003

\begin{tabular}{|c|c|c|c|c|c|}
\hline \multirow[b]{2}{*}{ Condição de atividade } & \multirow{2}{*}{$\begin{array}{l}\text { Casal sem } \\
\text { filhos }\end{array}$} & \multicolumn{4}{|c|}{ Casal com filhos e/ou parentes } \\
\hline & & $\begin{array}{c}\text { Casal até } 34 \\
\text { anos }\end{array}$ & $\begin{array}{c}\text { Casal de } 35 \text { a } \\
49 \text { anos }\end{array}$ & $\begin{array}{l}\text { Casal de } 50 \\
\text { anos e mais }\end{array}$ & Total (1) \\
\hline $1985(2)$ & 100,0 & 100,0 & 100,0 & 100,0 & 100,0 \\
\hline Cônjuge ocupada & 36,3 & 30,4 & 35,1 & 15,9 & 31,4 \\
\hline Cônjuge não-ocupada & 63,4 & 69,5 & 64,7 & 84,0 & 68,5 \\
\hline $1990(2)$ & 100,0 & 100,0 & 100,0 & 100,0 & 100,0 \\
\hline Cônjuge ocupada & 38,1 & 33,9 & 39,7 & 19,1 & 34,9 \\
\hline Cônjuge não-ocupada & 61,5 & 65,8 & 59,9 & 80,6 & 64,7 \\
\hline $1995(2)$ & 100,0 & 100,0 & 100,0 & 100,0 & 100,0 \\
\hline Cônjuge ocupada & 39,4 & 39,7 & 47,4 & 21,8 & 40,3 \\
\hline Cônjuge não-ocupada & 60,3 & 60,0 & 52,4 & 77,9 & 59,5 \\
\hline $2000(2)$ & 100,0 & 100,0 & 100,0 & 100,0 & 100,0 \\
\hline Cônjuge ocupada & 42,6 & 40,1 & 48,9 & 26,5 & 41,7 \\
\hline Cônjuge não-ocupada & 57,1 & 59,8 & 51,0 & 73,4 & 58,1 \\
\hline $2003(2)$ & 100,0 & 100,0 & 100,0 & 100,0 & 100,0 \\
\hline Cônjuge ocupada & 44,2 & 43,4 & 52,1 & 28,1 & 44,2 \\
\hline Cônjuge não-ocupada & 55,6 & 56,4 & 47,8 & 71,7 & 55,6 \\
\hline
\end{tabular}

Fonte: Convênio Seade-Dieese. Pesquisa de Emprego e Desemprego - PED. Elaboração da autora.

(1) O total de arranjos familiares inclui a categoria "residual" do tipo de arranjo familiar casal.

(2) Valor referente ao total da PIA para cônjuges inclui situações na ocupação maldefinidas. 
Os arranjos familiares de casais sem filhos apresentam, em todo o período, uma das mais elevadas taxas de ocupação das cônjuges. Em 1985, 36\% dessas mulheres eram ocupadas, oscilando ao redor de $39 \%$ até 1995. A partir de 1996, sua taxa de ocupação ultrapassou $42 \%$ e cresceu progressivamente até o final do período, chegando a cerca de $44 \%$, em 2003.

Constata-se que, a partir de 2000 , mais de $40 \%$ das cônjuges nos tipos de arranjos nucleados pelo casal - ou seja, casal sem filhos, casal de até 34 anos com filhos e casal de 35 a 49 anos com filhos - estavam ocupadas. Proporção menor só é encontrada nos arranjos familiares de casais de mais de 50 anos com filhos, nos quais pouco mais de um quarto das cônjuges encontravam-se ocupadas (Tabela 2).

A analise dos arranjos familiares de inserção das famílias das cônjuges, ocupadas e não-ocupadas evidencia a queda do número de ocupados entre chefes e filhos durante o período estudado.

Considerando-se o conjunto das famílias em que as cônjuges são ocupadas, é acentuada a redução da taxa de ocupação desses componentes familiares. Entre os chefes, cerca de $87 \%$ eram ocupados em 1985 , diminuindo para $83 \%$ em 1992, para $82 \%$ em 2000 e para cerca de $81 \%$, em 2003. No caso dos filhos, sua taxa de ocupação, que era de $37 \%$ em 1985 , se reduziu para 34\%, em 1992, e para 33\%, em 2000 e 2003. A contrapartida da redução da taxa de ocupação dos chefes e filhos no grupo de famílias em que as cônjuges são ocupadas é, principalmente, o aumento do desemprego; no caso dos chefes masculinos, em 2003, 10\% destes se encontravam desempregados e $9 \%$ na inatividade. No caso dos filhos, ao aumento do desemprego, que já era elevado, soma-se o crescimento da inatividade, especialmente para os menores de 18 anos. Entre os filhos, em 2003 , cerca de $15 \%$ eram desempregados e $53 \%$ inativos (Gráfico 3). Observam-se, assim, no período, redução do total de ocupados na família, que passaram de cerca de $73 \%$ da PIA em 1990 para $70 \%$ em 2003, e aumento da proporção da PIA em desemprego (de $5 \%$ para $8 \%$, no mesmo período). A proporção de inativos manteve-se em torno de $21 \%$, entre 1990 e 2003 (Gráfico 3).

Nas famílias nas quais a cônjuge feminina não é ocupada, os chefes de famí-

\section{GRÁFICO 3}

Distribuição das pessoas com dez anos e mais das famílias com cônjuge feminina ocupada, por posição na família, segundo situação ocupacional e condição de precariedade dos postos de trabalho Região Metropolitana de São Paulo - 1985-2003

$\mathrm{Em} \%$

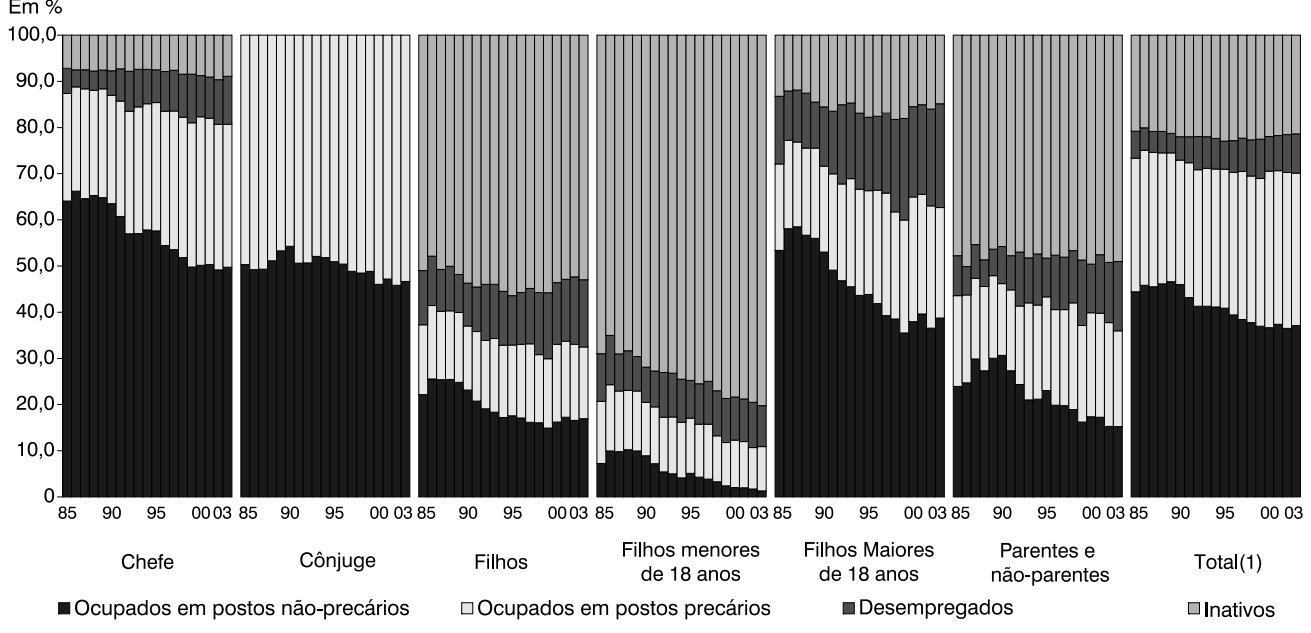

Fonte: Convênio Seade-Dieese. Pesquisa de Emprego e Desemprego - PED. Elaboração da autora.

(1) Inclui outros e exclui empregados domésticos e pensionistas. 
lia e os filhos são os principais mantenedores e, para ambos, observam-se acentuada redução no total de ocupados e aumento da proporção da PIA em desemprego; para os chefes masculinos, acentuase a partir de 1997 o aumento da inatividade. No caso das famílias das cônjuges não-ocupadas, em 1985, 79\% dos chefes e $45,4 \%$ dos filhos eram ocupados. Esse número diminuiu para $75 \%$ e $41 \%$, respectivamente, em 1992. Já em 2000, apenas $72 \%$ dos chefes se mantinham ocupados, decrescendo para 69\%, em 2003. Assim, a redução dos chefes ocupados no período analisado é de 10 pontos percentuais, sendo que se distribuem de forma semeIhante, acrescentando-se ao desemprego e à inatividade (Gráfico 4); em 2003, 9\% dos chefes masculinos estavam desempregados e $22 \%$ em inatividade. Entre os filhos, a queda da taxa de ocupação é menos abrupta que a dos chefes, embora tenha se acentuado entre 1996 e 1999. Em 2000 e 2003 , cerca de $39 \%$ dos filhos estavam ocupados, $16 \%$ desempregados e $45 \%$ na inatividade (Gráfico 4).

A redução dos ocupados nas famílias é conseqüência do aumento do desemprego e da inatividade dos seus componentes. A crescente precarização dos postos de trabalhos dos componentes ocupados, que causou, juntamente com o aumento do desemprego, a diminuição dos rendimentos individuais e da renda familiar, como será visto a seguir, sem dúvida impulsionou uma parcela das cônjuges para o mercado de trabalho na tentativa de preservar as condições de vida da família.

Nesse contexto, parte das cônjuges não-ocupadas mobilizou-se para o mercado a partir de 1992, mas permaneceu desempregada. Indicações de maior mobilização em busca de trabalho são evidenciadas desde 1996 pela taxa de desemprego de $12 \%$, acentuando-se a partir do final da década de 90 , caracterizado pelo recrudescimento do desemprego, e nos anos 2000; em 2003, 20\% das cônjuges não-ocupadas buscavam emprego. Devese mencionar ainda que, em decorrência das características de inserção apresentadas pelo conjunto dos componentes e não apenas da cônjuge, neste grupo de famílias, comparativamente às famílias das cônjuges ocupadas, é bastante menor a proporção de ocupados, da ordem de $41 \%$ da PIA em 1990 e de $36 \%$ em 2003. São também mais elevadas a proporção de desempregados (cerca de 6\% da PIA familiar em 1990 e 15\% em 2003) e a taxa de inatividade, em torno de $51 \%$ de 1990 até 1998 e de $49 \%$ em 2003 (Gráfico 4).

Tanto nas famílias das cônjuges ocupadas como nas das não-ocupadas, além da redução da proporção de ocupados, observa-se também a precarização do trabalho como expressão do processo que ocorre no mercado de trabalho da Região Metropolitana de São Paulo. Além do grande número de desempregados, muitos dos indivíduos que permaneceram no mercado de trabalho sofreram com a precarização de seus empregos. O número de trabalhadores assalariados e com carteira de trabalho diminuiu, enquanto o de autônomos, assalariados sem registro, empregados domésticos e trabalhadores familiares aumentou.

Entre os componentes em idade ativa das famílias com cônjuges ocupadas, em 1990, 45\% estavam em postos de trabalhos não-precários e $29 \%$ em precários. Em 1992, já eram 40,9\% entre os postos nãoprecários e $30 \%$ entre os precários. Entre 2000 e 2003 , cerca de $37 \%$ se mantinham em postos não-precários, enquanto cerca de $34 \%$ dos componentes encontravam-se em ocupações precarizadas. ${ }^{4}$

A análise considerando os componentes em idade ativa das famílias das cônjuges ocupadas evidencia que todos sofreram os efeitos da precarização nos postos de trabalho. Entre os chefes masculinos, em $1985,63 \%$ estavam em postos não-

${ }^{4}$ Como aproximação de vinculações não-precárias no mercado de trabalho, foram considerados os assalariados regulamentados, com registro em carteira, do setor público e os empregadores. Como aproximação de vinculações precárias no mercado de trabalho, consideram-se os assalariados sem registro, autônomos, empregados domésticos e trabalhadores familiares. 
precários e $23,6 \%$ em precários. A partir de 1990, ocorreu contínua redução nos postos de trabalho não-precários. Em 1995 cerca de $56 \%$ dos chefes estavam em trabalhos não-precários e cerca de $27 \%$ em precários. Em queda progressiva a partir de 1996, menos da metade, ou seja, $49 \%$ dos chefes masculinos estavam em empregos não-precários em 2000 e 2003 e cerca de $31 \%$ em postos precários. A partir de 1997, soma-se à redução dos postos não-precários a queda na proporção de ocupados.

Considerando-se as cônjuges ocupadas, em 1985, quase a metade $(49,9 \%)$ delas estava em postos não-precários e a outra metade em postos precários. Com oscilações, este quadro se manteve até 1996. A partir de 1997, ocorreu a tendência de redução dos postos não-precários e de elevação dos precários. Entre 2000 e 2003, apenas $45 \%$ das cônjuges ocupadas se mantinham em empregos não-precários, enquanto $55 \%$ encontravam-se em ocupações com vinculações precárias.
Os filhos também registraram redução dos postos não-precários e experimentaram de forma mais acentuada o aumento do desemprego. Para aqueles maiores de 18 anos, diminuiu a proporção de ocupados. Em 1990, 71\% da PIA específica dos filhos maiores era ocupada e $52 \%$ se encontrava em postos não-precários. Em 2000, 65\% da PIA era ocupada, decrescendo para apenas $63 \%$ em 2003 , dos quais cerca de $38 \%$ estavam em empregos não-precários e cerca de $24 \%$ naqueles precários. A proporção de desempregados chegou a 22,3\% da PIA específica em 2003 (Gráfico 3).

Entre os componentes em idade ativa das famílias de cônjuges não-ocupadas, $30 \%$ tinham postos de trabalhos nãoprecários e $11 \%$ estavam em trabalhos precários em 1985. Em 1992, 27\% continuavam em postos não-precários, enquanto $12 \%$ inseriam-se em postos precarizados. Entre 2000 e 2003, a precarização acentuou-se e apenas cerca de $21 \%$ dos componentes em idade ativa se mantiveram em postos não-precários,

GRÁFICO 4

Distribuição das pessoas de dez anos e mais das famílias com cônjuge feminina não-ocupada, por posição na família, segundo situação ocupacional e condição de precariedade dos postos de trabalho Região Metropolitana de São Paulo - 1985-2003

$\mathrm{Em} \%$

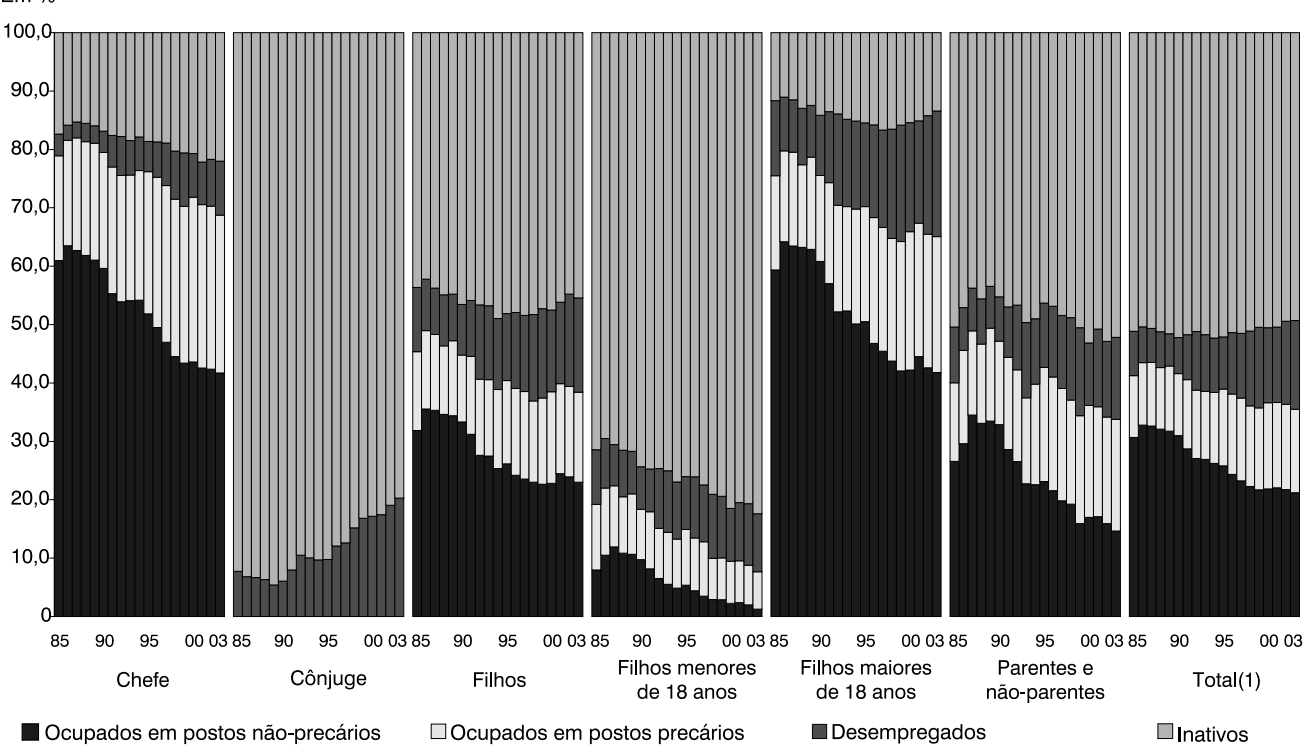

Fonte: Convênio Seade-Dieese. Pesquisa de Emprego e Desemprego - PED. Elaboração da autora.

(1) Inclui outros e exclui empregados domésticos e pensionistas. 
enquanto cerca de $15 \%$ estavam entre autônomos, assalariados sem registro, empregados domésticos e familiares. Devese recordar que, em 2003, apenas 36\% da PIA deste grupo de famílias estava na condição de ocupados.

A partir dos anos 90, tanto os chefes como os filhos registraram acentuada redução de postos de trabalho não- precários e crescimento da proporção de precários (Gráfico 4). Em 1985, 60,2\% dos chefes e $31,6 \%$ dos filhos em idade ativa (PIA) das famílias de cônjuges femininas não-ocupadas tinham postos de trabalho nãoprecários, passando, em 1992, respectivamente, para $53,2 \%$ e $27,4 \%$. Em 2000 , $43 \%$ dos chefes estavam em ocupações não-precárias, diminuindo para $41 \%$ em 2003 , enquanto cerca de $27 \%$ encontravam-se em ocupações precárias. No caso dos filhos, em 2000 e 2003, cerca de $23 \%$ estavam em postos não-precários e 15\% em inserções precárias. Para ambos, cresceu o desemprego a partir de 1997 e para os chefes masculinos também aumentou a inatividade nesse período.

A análise da distribuição das pessoas que contribuem com algum rendimento para a renda familiar evidencia, para as famílias em que a cônjuge é ocupada, aumento dos componentes do casal (chefes e cônjuges) na proporção dos que contribuem, em detrimento da dos filhos.

Também nas famílias das cônjuges não-ocupadas, observa-se crescimento da participação destas entre os que aportam rendimentos para a composição da renda familiar.

Ainda que no conjunto dos componentes familiares cresça a proporção dos que aportam rendimentos para o núcleo doméstico, foi acentuada a queda da renda familiar per capita nesse período, para todos os tipos de família, especialmente a partir de 1996, como conseqüência da redução do rendimento proveniente do trabalho. Nem mesmo o aumento de rendimento de outras fontes que não do trabalho (aposentadorias e pensões) impediu sua queda.

A participação dos membros da família na composição da renda familiar evidencia as mudanças na divisão do trabalho na família, no período analisado. Uma tendência comum a todos os arranjos familiares nucleados pelo casal é o aumento da participação da cônjuge na renda familiar, fato que vem sendo apontado

GRÁFICO 5

Rendimento médio, por posição na família

Em reais de dezembro de 2003

Região Metropolitana de São Paulo - 1986-2003

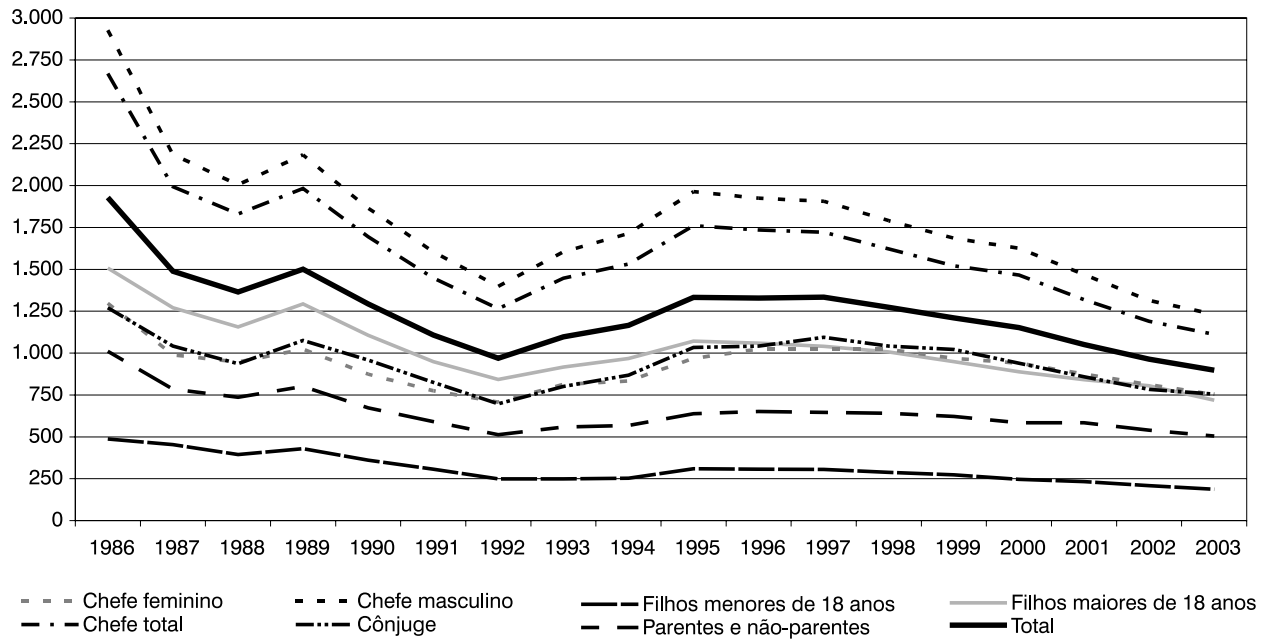

Fonte: Convênio Seade-Dieese. Pesquisa de Emprego e Desemprego - PED. Elaboração da autora. 
TABELA 3

Participação na composição da massa de renda familiar, por posição na família Região Metropolitana de São Paulo - 1986-2003

\begin{tabular}{|c|c|c|c|c|c|c|c|}
\hline Anos & Chefe & Cônjuge & Filhos & $\begin{array}{c}\text { Filhos } \\
\text { menores de } \\
18 \text { anos }\end{array}$ & $\begin{array}{c}\text { Filhos } \\
\text { maiores de } \\
18 \text { anos }\end{array}$ & $\begin{array}{c}\text { Parentes e } \\
\text { não-parentes }\end{array}$ & Total (1) \\
\hline \multicolumn{8}{|c|}{ Total das famílias } \\
\hline 1986 & 68,0 & 11,0 & 16,2 & 1,8 & 14,4 & 4,1 & 100,0 \\
\hline 1990 & 65,5 & 12,5 & 16,8 & 1,6 & 15,2 & 4,7 & 100,0 \\
\hline 1995 & 65,9 & 14,8 & 14,7 & 1,1 & 13,6 & 4,1 & 100,0 \\
\hline 2000 & 65,3 & 15,9 & 14,4 & 0,7 & 13,7 & 3,8 & 100,0 \\
\hline 2003 & 63,3 & 17,3 & 14,9 & 0,6 & 14,4 & 3,9 & 100,0 \\
\hline \multicolumn{8}{|c|}{$\begin{array}{l}\text { Cônjuge feminina } \\
\text { ocupada }\end{array}$} \\
\hline 1986 & 60,1 & 28,9 & 8,7 & 1,7 & 7,0 & 2,3 & 100,0 \\
\hline 1990 & 56,9 & 32,1 & 8,6 & 1,5 & 7,2 & 2,3 & 100,0 \\
\hline 1995 & 57,8 & 33,4 & 7,1 & 1,0 & 6,1 & 1,7 & 100,0 \\
\hline 2000 & 55,8 & 34,8 & 7,9 & 0,6 & 7,3 & 1,4 & 100,0 \\
\hline 2003 & 54,2 & 36,2 & 8,0 & 0,5 & 7,5 & 1,5 & 100,0 \\
\hline \multicolumn{8}{|c|}{$\begin{array}{l}\text { Chefe feminina } \\
\text { ocupada sem cônjuge }\end{array}$} \\
\hline 1986 & 63,9 & 0,0 & 22,3 & 3,3 & 19,1 & 11,4 & 100,0 \\
\hline 1990 & 63,3 & 0,0 & 22,5 & 2,7 & 19,8 & 12,1 & 100,0 \\
\hline 1995 & 69,1 & 0,0 & 19,3 & 1,9 & 17,4 & 9,9 & 100,0 \\
\hline 2000 & 72,2 & 0,0 & 17,4 & 1,1 & 16,3 & 9,0 & 100,0 \\
\hline 2003 & 72,6 & 0,0 & 17,8 & 1,0 & 16,8 & 8,5 & 100,0 \\
\hline
\end{tabular}

Fonte: SEP - Convênio Seade-Dieese. Pesquisa de Emprego e Desemprego - PED. Elaboração da autora. (1) Inclui outros.

também por outros estudos recentes (LEONE, 2000 e 2004; DEDECCA, 2005). No contexto de elevado desemprego, baixo crescimento da economia e desvalorização dos salários, as cônjuges vêm participando crescentemente de atividades no mercado de trabalho, aumentando assim sua participação na renda da família. Cresceu não só o número de cônjuges auxiliando na renda familiar, mas também a importância dessa sua contribuição (Tabela 3).

Considerando-se a média das cônjuges, seus rendimentos individuais representavam, em 1986, $11 \%$ da massa da renda familiar, passando para cerca de $16 \%$ em 2000 e $17 \%$ em 2003, com diferenciações na evolução da participação por tipo de arranjo familiar (Tabela 3). A contribuição dos chefes masculinos diminuiu de $68 \%$, em 1986, para $63,3 \%$, em 2003 , e a dos filhos reduziu-se de $16,2 \%$ para $14,9 \%$, no período.

Porém, ao se selecionarem as famílias das cônjuges ocupadas, constata-se que é mais elevada sua participação na com- posição da renda familiar: em 1986, elas contribuíam com cerca de $29 \%$ da massa da renda familiar e os chefes masculinos, com $60 \%$; em 2000 , esses valores correspondiam a, respectivamente, $35 \%$ e $56 \%$; e, em 2003, a $36 \%$ e $54 \%$ (Tabela 3). Estas cifras evidenciam maior partilhamento na responsabilidade da manutenção do núcleo doméstico entre estes dois componentes, considerando que os filhos maiores de 18 anos contribuíam, em média com $8 \%$ da renda nas famílias em que as cônjuges são ocupadas.

Assim, nas famílias em que a cônjuge é ocupada, a partir de 1990 - já sob a reestruturação produtiva -, estabeleceu-se um padrão de responsabilidade pela manutenção da família, que se acentuou a partir dos anos de maior desemprego do final da década de 90 , com progressiva redução da contribuição do chefe masculino e crescente participação da cônjuge feminina como co-provedora.

Mesmo nas famílias em que a cônjuge não é ocupada, observa-se relativo cres- 
cimento da participação das cônjuges na renda familiar. Nestas, em 1986, $79 \%$ da renda familiar era provida pelo chefe, $1 \%$ pela cônjuge e 19\% pelos filhos. Em 2000, $77 \%$ eram de responsabilidade dos chefes, $4 \%$ das cônjuges e 18\% dos filhos. Em 2003 a participação do chefe diminuiu um pouco, para $73,2 \%$, as cônjuges contribuíam com $5,4 \%$ e os filhos com 18,3\% (Gráfico 7 ), indicando o crescimento da importância do rendimento das cônjuges não-ocupadas proveniente de trabalhos esporádicos do desempregado ou inativo e mesmo aposentadorias e pensões - para a renda familiar no período estudado. Outros estudos de natureza qualitativa sobre o desemprego indicam a atividade intensa, não apenas no mercado de trabalho, das mulheres desempregadas (SEGNINI, 2004).

\section{Chefes femininas: características da} inserção familiar no mercado de trabalho e contribuição para a provisão da família

Os arranjos familiares das chefes femininas sem cônjuge, considerando os momentos do ciclo vital familiar, concentram-se nas etapas mais avançadas deste. Cerca de $40 \%$ das chefes femininas têm 50 anos ou mais. Nesta etapa a reprodução biológica está completada e parte dessas mulheres dirige-se para a inatividade ou aposentadoria. Muitos desses domicílios, cerca de um terço, são unipessoais.

Correspondendo à fase intermediária do ciclo vital das famílias, ou seja, a etapa da expansão (idades das chefes entre 35 e 49 anos), estão cerca de um terço das famílias das chefes femininas. Destas, apenas $13 \%$ são unipessoais. Entre as famílias das chefes femininas correspondendo à etapa inicial da família (idades das chefes até 34 anos), caracterizada pelo início da reprodução biológica, estão cerca de $20 \%$ delas, sendo um quarto unipessoais. Estas características afetarão os arranjos de inserção deste tipo de família - chefe feminina sem a presença de cônjuge - que tem aumentado numericamente e que, em 2003 representava $24 \%$ das famílias na Região Metropolitana

\section{GRÁFICO 6}

Participação na composição da renda familiar nas famílias com cônjuge feminina ocupada, por posição na família, segundo arranjos familiares

$\mathrm{Em} \%$

100,0

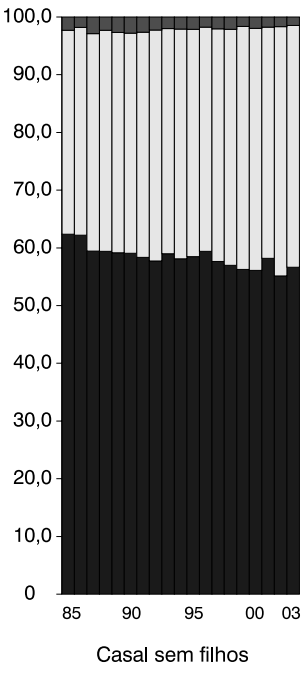

Chefe

$\square$ Cônjuge
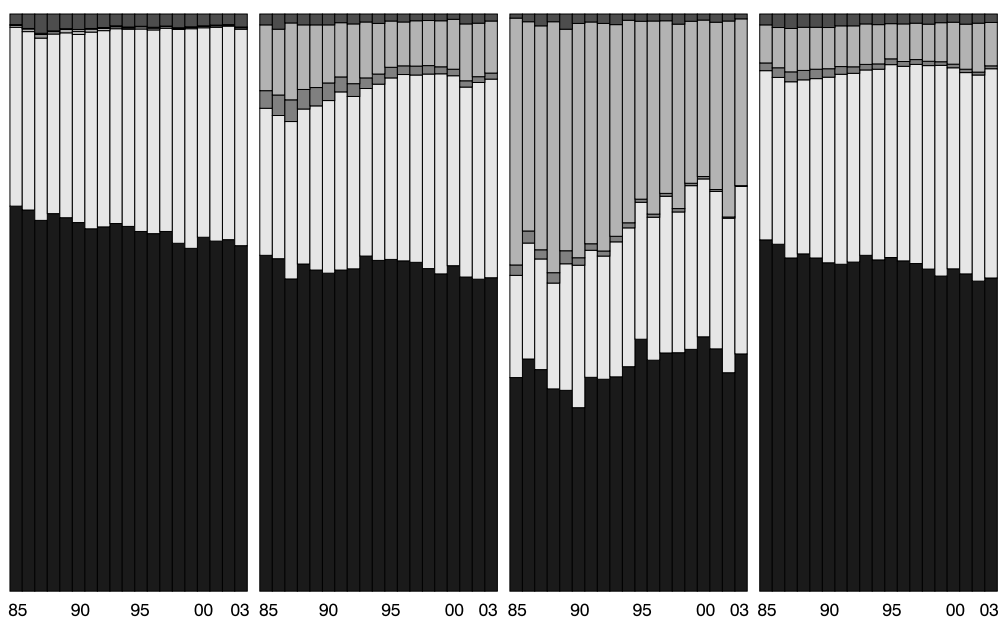

Casal até 34 anos

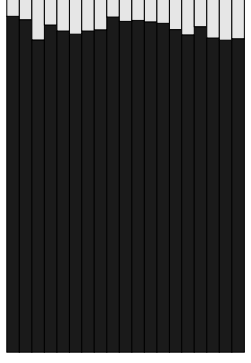

90
Casal de 35

49 anos

$90 \quad 95$ e mais

Filhos menores de 18 anos

Filhos maiores de 18 anos

Fonte: SEP - Convênio Seade-Dieese. Pesquisa de Emprego e Desemprego - PED. Elaboração da autora.

(1) Inclui outras configurações familiares. 
GRÁFICO 7

Participação na composição da renda familiar nas famílias com cônjuge feminina não-ocupada, por posição na família, segundo arranjos familiares

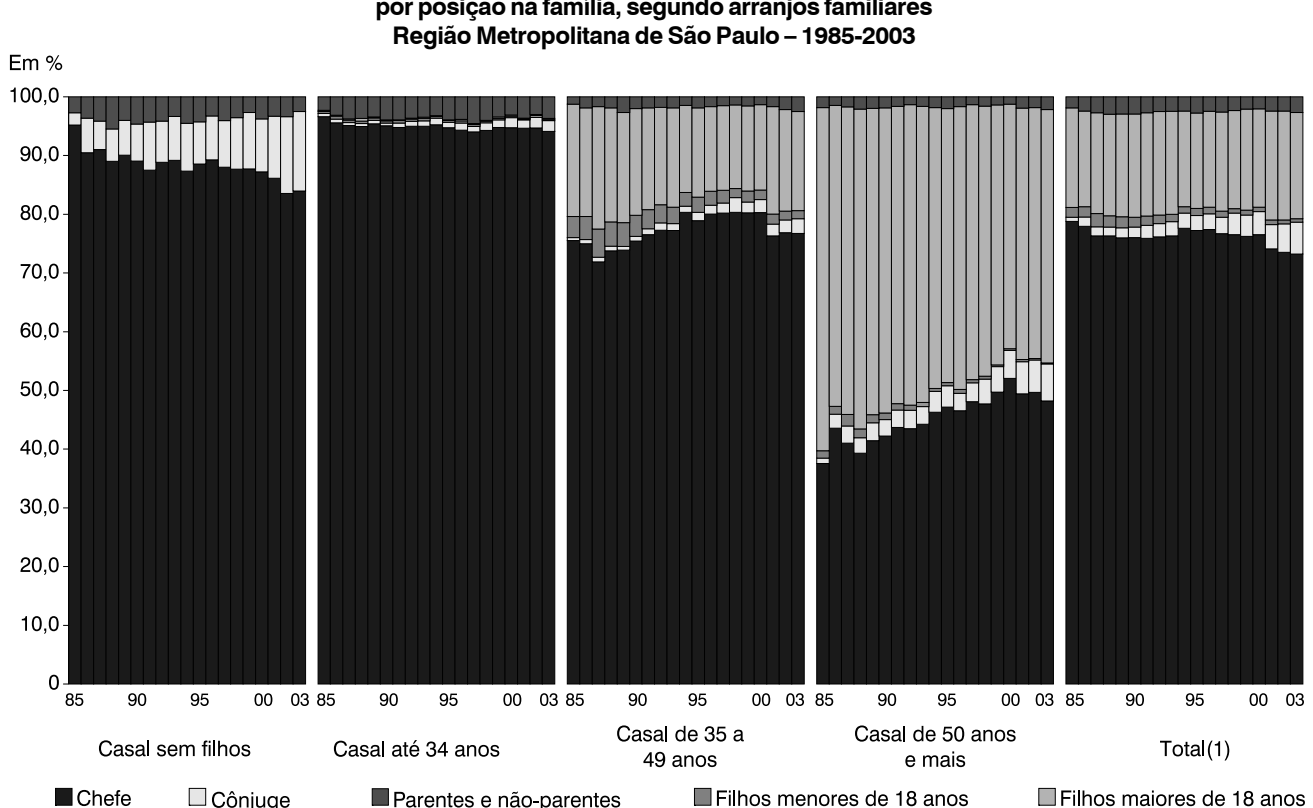

Fonte: SEP - Convênio Seade-Dieese. Pesquisa de Emprego e Desemprego - PED. Elaboração da autora.

(1) Inclui outras configurações familiares.

de São Paulo, como pode ser visto na Tabela $1 .^{5}$

A análise dos arranjos familiares nucleados pela chefe feminina sem cônjuge evidencia, no período estudado, o aumento da participação das chefes no mercado de trabalho. A taxa de participação das chefes sem cônjuge era da ordem de $56 \%$, em 1990 , passando para $60 \%$, em 2000 e 2003 (Gráfico 1). Como a taxa de ocupação das chefes oscila ao redor de $52 \%$, evidenciando a não expansão da absorção pelo mercado de trabalho, tem crescido entre os anos 90 e 2000 a proporção de desempregadas, que, em 1990, correspondiam a cerca de $5 \%$ da PIA específica e, em 2003, a $9 \%$.

A mobilização das chefes femininas sem cônjuge para o mercado de trabalho caracteriza-se por ser elevada e intensificase nos anos 90, concomitante ao aumento do desemprego e da inatividade dos filhos.
As mudanças no padrão de inserção no mercado de trabalho, na década de 90, causaram maiores dificuldades para a inserção de jovens (POCHMANN, 1998), o que diminuiu as taxas de participação dos filhos destes arranjos familiares.

A composição da PIA nas famílias de chefes femininas ocupadas evidencia a redução da absorção dos filhos pelo mercado de trabalho: sua taxa de ocupação passou de $49,7 \%$, em 1985 , para $43,8 \%$, em 1992, 41,3\%, em 2000, e 38\%, em 2003. A proporção de desempregados para os filhos das famílias de chefes femininas ocupadas era de $14,2 \%$ da PIA específica, em 1985, e intensificou-se na década de 90 , a partir de 1992, quando passou para $17,5 \%$, ficando em cerca de $19 \%$ entre 2000 e 2003 (Gráfico 8).

Entre as famílias das chefes femininas não-ocupadas, é mais elevada a taxa de ocupação dos filhos, porém decresce no

${ }^{5}$ Não é possível desagregar esse arranjo familiar por grupos de idade para análise por não apresentar significância estatística. 
período analisado: $62,8 \%$, em $1985,58,9 \%$, em 1992, e cerca de 52\%, em 2000 e 2003. Em complementaridade, cresceu a proporção de desempregados entre os filhos das famílias de chefes femininas nãoocupadas, passando de $14 \%$ da PIA em 1985 para $17 \%$ em 2000 e $18 \%$ em 2003 (Gráfico 9).

A intensificação do desemprego para os filhos, como se observou também para as famílias das cônjuges ocupadas e das não-ocupadas, ocorreu a partir de 1992, recrudescendo no final da década de 90 até 2003. Esta tendência corresponde ao crescimento do desemprego dos jovens apontado anteriormente.

Ao mesmo tempo em que aumenta a proporção de desempregados, observa-se também nas famílias das chefes femininas a precarização dos postos de trabalho. Dessa maneira, concomitante ao grande número de desempregados, ocorre a precarização do emprego para os indivíduos que permanecem no mercado de trabalho. Ou seja, diminui o número de trabalhadores assalariados com carteira de trabalho e aumenta o de autônomos e assalariados sem registro.
Um breve exame dos componentes em idade ativa das famílias das chefes femininas não-ocupadas mostra que, em 1985 , os ocupados representavam $35 \%$ desse arranjo familiar, dos quais $25 \%$ se inseriam em postos de trabalhos nãoprecários e 10\% em precários. Em 1992, apenas $22 \%$ permaneciam em postos nãoprecários, enquanto $10 \%$ encontravam-se em ocupações precárias. Entre 2000 e 2003 , apenas $16 \%$ dos componentes em idade ativa se mantinham em postos nãoprecários e cerca de $12 \%$ estavam inseridos como autônomos, assalariados sem registro, empregados domésticos e familiares. A baixa proporção de ocupados quando comparada às famílias em que as chefes femininas são ocupadas se acentua a partir de 1997, ano que se iniciou o recrudescimento do desemprego na RMSP.

Entre os componentes em idade ativa das famílias nas quais as chefes femininas são ocupadas, $42,8 \%$ estavam em postos de trabalhos não-precários e 27,9\% em precários, em 1985, passando, respectivamente, para $33 \%$ e $32,5 \%$, em 2000 . Essa redução tem continuidade e, em 2003 , menos de um terço $(30,5 \%)$ se mantinha em postos

GRÁFICO 8

Distribuição das pessoas de dez anos e mais das famílias com chefe feminina ocupada, por posição na família, segundo situação ocupacional e condição de precariedade dos postos de trabalho

$\mathrm{Em} \%$ Região Metropolitana de São Paulo - 1985-2003
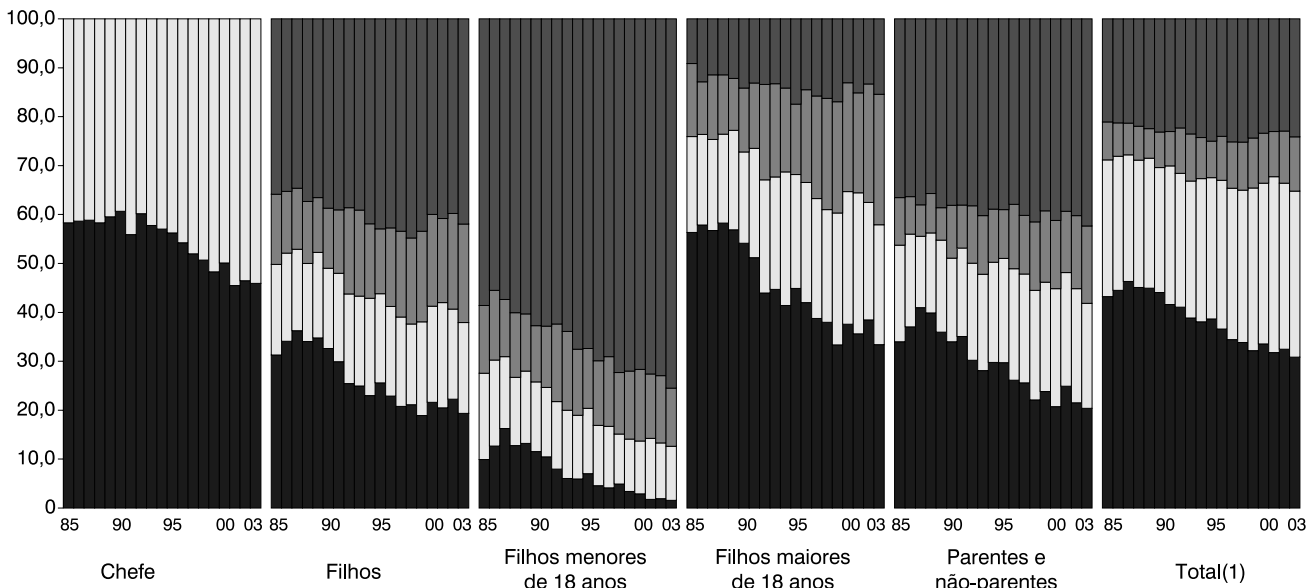

Ocupados em postos não-precários Filhos menores de 18 an

Tesempregados

Inativos

Fonte: Convênio Seade-Dieese. Pesquisa de Emprego e Desemprego - PED. Elaboração da autora. (1) Inclui outros e exclui empregados domésticos e pensionistas 


\section{GRÁFICO 9}

Distribuição das pessoas de dez anos e mais das famílias com chefe feminina não-ocupada, por posição na família, segundo situação ocupacional e condição de precariedade dos postos de trabalho Região Metropolitana de São Paulo - 1985-2003

Em \%

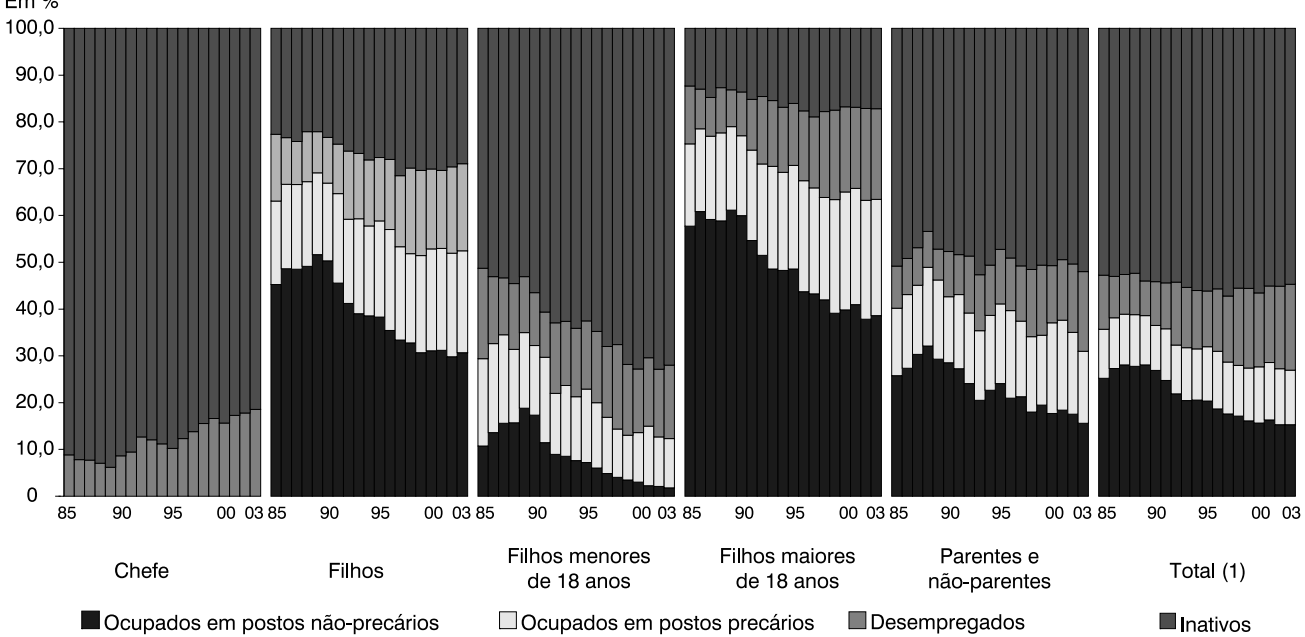

Fonte: Convênio Seade-Dieese. Pesquisa de Emprego e Desemprego - PED. Elaboração da autora. (1) Inclui outros e exclui empregados domésticos e pensionistas.

não-precários e 33,6\% estavam em ocupações precárias (Gráfico 8).

A precarização do trabalho atinge a todos os componentes em idade ativa das famílias das chefes femininas ocupadas (Gráfico 8). Em 1985, mais da metade das chefes femininas $(57,9 \%)$ encontrava-se ocupada em postos não-precários e 41,4\% estavam em postos precários. Em 2000, essas proporções se dividem igualmente, com cerca de $49 \%$ em precários e $49 \%$ em não-precários. Entre 2001 e 2003, acentuou-se a precarização, reduzindo-se para cerca de $45 \%$ aquelas em postos nãoprecários e chegando a $53 \%$ em postos precários.

Observam-se duas tendências na inserção ocupacional dos filhos nesse arranjo familiar: menor parcela ocupada e tendência de queda dos ocupados nãoprecários no decorrer dos anos 90 . Em $1985,31 \%$ dos filhos estavam em postos não-precários e 18,4\% em precários. Já em 2000 , estes valores correspondiam a, respectivamente, $21,5 \%$ e $19,7 \%$. O ano de 2003 indica agravamento das condições de inserção dos filhos no mercado de trabalho, quando diminuiu a proporção de ocupados - 19\% sob vinculações não-precárias e 18\% em precárias -, $20 \%$ estavam em situação de desemprego e $42 \%$ na inatividade (Gráfico 8).

O aumento do desemprego e a crescente precarização dos postos de trabalhos dos componentes em idade ativa causam a diminuição dos rendimentos individuais e da renda familiar. Nesse contexto, os rendimentos das chefes femininas tornamse cada vez mais importantes na composição da renda familiar e na preservação das condições de vida da família.

A análise da participação dos componentes familiares na composição da renda familiar evidencia, no decorrer dos anos 90, que cresce tanto a proporção das chefes femininas participando na renda familiar quanto a importância da sua contribuição na composição dessa renda (Tabela 3, Gráficos 10 e 11).

As chefes femininas ocupadas sempre tiveram uma participação importante na composição da renda familiar, mas de 1985 até 2000 essa importância aumentou ainda mais. Em 1986, 64\% da renda familiar era 


\section{GRÁFICO 10}

Participação na composição da renda familiar nas famílias com chefe feminina ocupada sem cônjuge,

por posição na família

Região Metropolitana de São Paulo - 1985-2003

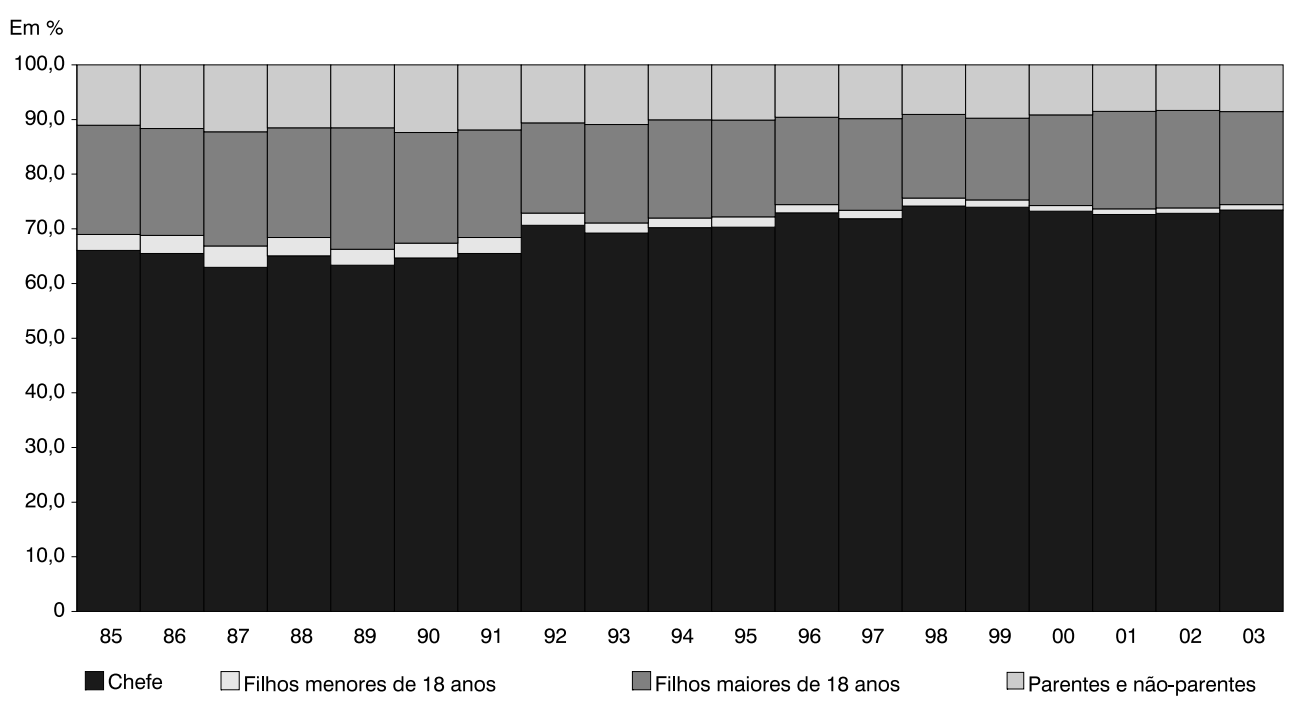

Fonte: Convênio Seade-Dieese. Pesquisa de Emprego e Desemprego - PED. Elaboração da autora.

GRÁFICO 11

Participação na composição da renda familiar nas famílias com chefe feminina não-ocupada sem cônjuge, por posição na família

Região Metropolitana de São Paulo - 1985-2003

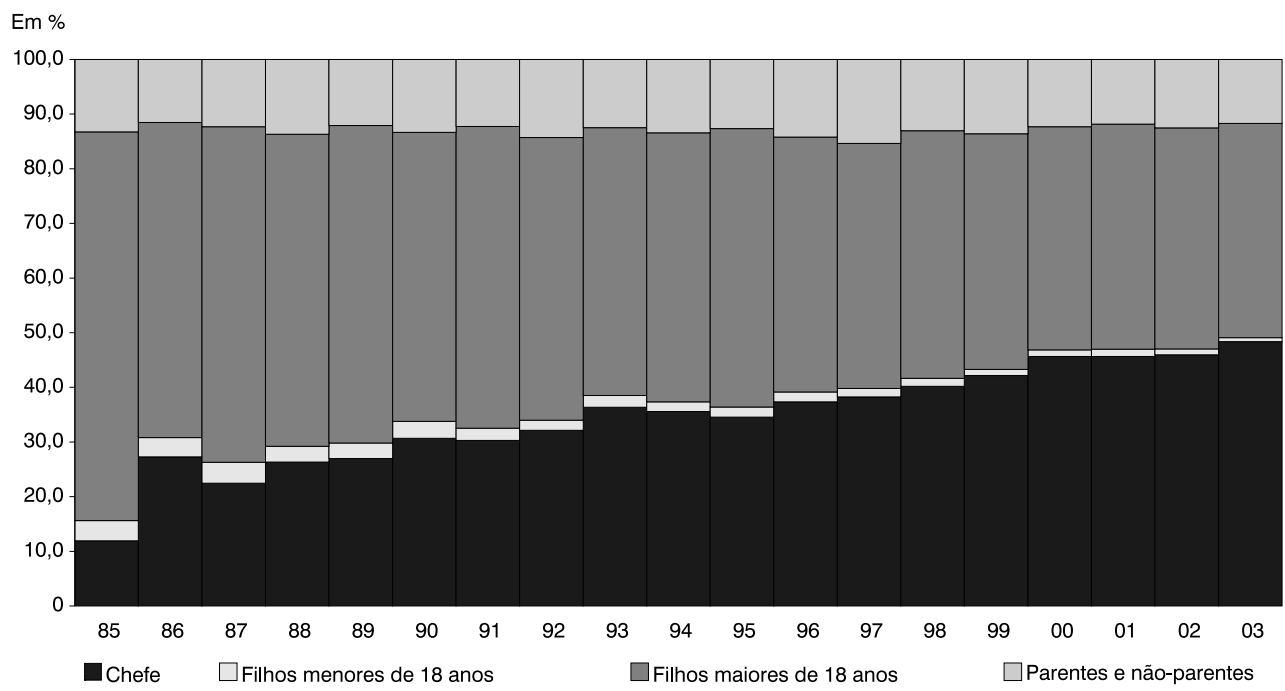

Fonte: Convênio Seade-Dieese. Pesquisa de Emprego e Desemprego - PED. Elaboração da autora. 
de responsabilidade das chefes e $22 \%$ dos filhos. Em 2000 e 2003, as chefes ocupadas eram responsáveis por mais de $72 \%$ da renda familiar, enquanto os filhos respondiam por pouco mais de 17\% (Gráfico 10). Nessas famílias, pode-se observar que a cada ano há uma menor participação dos filhos na renda familiar e, dessa forma, é a participação crescente das chefes femininas no mercado de trabalho que permite a provisão dessas famílias.

Nas famílias das chefes femininas nãoocupadas, altera-se profundamente a responsabilidade pela provisão da família no período analisado. Registra-se elevação da participação da chefe feminina, principalmente no decorrer dos anos 90, acentuando-se a partir do final dessa década marcada pelo mais elevado desemprego. Desde o ano 2000, a chefe feminina não-ocupada passa a ser o componente familiar com contribuição maior na composição da renda familiar. Assim, em 1986, 27\% da renda familiar era provida pela chefe e $61 \%$ pelos filhos. Já em 2000 esses valores passaram para $45 \%$ e $42 \%$, respectivamente. Em 2003, a participação das chefes aumentou ainda mais, chegando a $48 \%$ e a dos filhos diminuiu para $38 \%$ (Gráfico 11). Isto demonstra o crescimento da importância dos rendimentos das chefes femininas não-ocupadas - provenientes de aposentadorias e pensões, bem como de trabalhos esporádicos - para a provisão familiar no período estudado. Por outro lado, a precarização do trabalho e o desemprego dos filhos atuaram reduzindo seu aporte para a renda familiar.

Um último aspecto a ser ressaltado refere-se à contribuição tanto das cônjuges como das chefes femininas enquanto provedoras e co-provedoras e aos impactos da sua participação nos rearranjos familiares de inserção no mercado de trabalho, a partir dos anos 90 .

Constatou-se que, tanto no caso das cônjuges ocupadas como no das chefes femininas, sua participação na composição do rendimento domiciliar elevou a renda familiar per capita (Gráficos 12 e 13).

GRÁFICO 12

Rendimento familiar per capita médio em famílias com chefe feminina sem cônjuge, segundo condição de ocupação Região Metropolitana de São Paulo 1986-2003

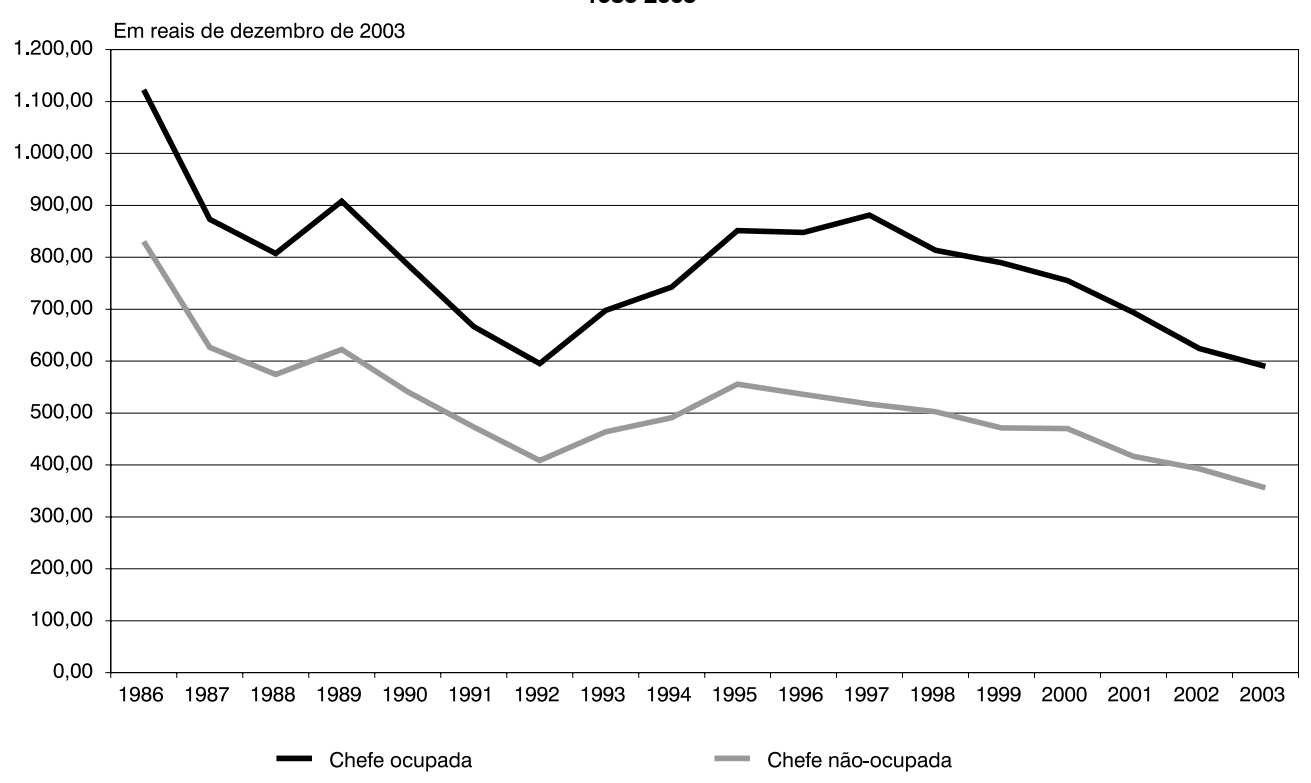

Fonte: Convênio Seade-Dieese. Pesquisa de Emprego e Desemprego - PED. Elaboração da autora. 


\section{GRÁFICO 13}

Rendimento familiar per capita médio em famílias com cônjuge feminina, segundo condição de atividade Região Metropolitana de São Paulo - 1986-2003

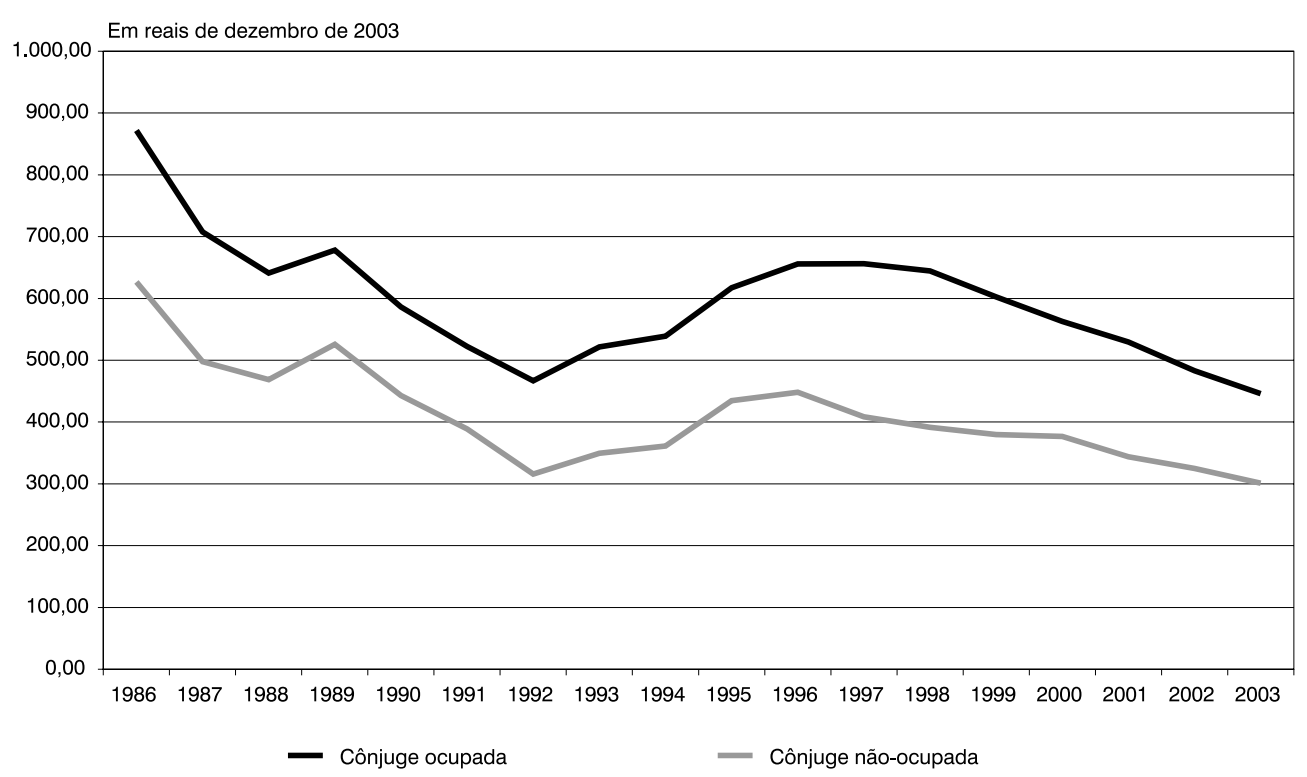

Fonte: Convênio Seade-Dieese. Pesquisa de Emprego e Desemprego - PED. Elaboração da autora.

Constatou-se também que o impacto do rendimento das cônjuges e das chefes de família na renda familiar e nas condições de sobrevivência da família acentuou-se no decorrer da década de 90. Isso fica mais evidente quando se compara o período de maior desemprego do final da década de $90 \mathrm{com}$ o ano de 1989, tomado como referência do período a partir do qual se intensificou a reestruturação produtiva na RMSP e se alterou o padrão de absorção da força de trabalho. Verifica-se que, em 1989, o rendimento familiar per capita das famílias com cônjuges ocupadas era 31\% superior ao daquelas cuja cônjuge não estava ocupada e, nas famílias das chefes femininas, essa diferença era de $25 \%$ entre as ocupadas e não-ocupadas.

Essa diferença acentuou-se a partir do final da década de 90 (1997-1999). Durante esse período, o rendimento familiar per capita era cerca de $40 \%$ mais elevado nas famílias em que a cônjuge era ocupada. No inicio dos anos 2000, aqui analisados, essa diferença ficou em torno de $39 \%$, porém mantendo-se maior do que no início da década de 90 (Gráfico 12).

No caso das famílias das chefes femininas, é bastante significativo o nível mais elevado da renda familiar quando estas são ocupadas (Gráfico 13). Nesses anos do final da década de 90 , o rendimento familiar per capita das famílias das chefes femininas ocupadas tornou-se cerca de $38 \%$ mais elevado. No inicio dos anos 2000 , essa diferença diminuiu um pouco, permanecendo cerca de $33 \%$ mais elevada.

\section{Considerações finais}

O conjunto de dados analisados evidenciou, no período estudado, o crescimento da inserção das cônjuges femininas e das chefes femininas sem cônjuge no mercado de trabalho, bem como o aumento de sua contribuição na composição da renda familiar, mostrando o impacto dos rearranjos familiares predominantes, articulados sob 
a reestruturação produtiva e a precarização do trabalho.

A participação crescente destes componentes familiares na composição da renda familiar possibilitou atenuar o empobrecimento das famílias na Região Metropolitana de São Paulo, especialmente no final da década de 90 e início dos anos 2000, que apresentaram os mais elevados níveis de desemprego e de acentuação da precarização do trabalho.

\section{Referências bibliográficas}

APPAY, B. Précarisation sociale et restructurations productives. In: APPAY, B.; THÉBAUD-MONY, A. Précarisation sociale, travail et santé. Paris: Iresco, 1997.

ABRAMO, L. Insercion laboral de las mujeres em América Latina: uma fuerza de trabajo secundaria? In: SEMINÁRIO TEMÁTICO INTERDICIPLINAR OS ESTUDOS DO TRABALHO: NOVAS PROBLEMÁTICAS NOVAS METODOLOGIAS E NOVAS ÁREAS DE PESQUISA. Campinas, Unicamp, novembro, 2000.

ARAÚJO, C.; SCALON, C. (Orgs.). Gênero, família e trabalho no Brasil. Rio de Janeiro: Editora da Fundação Getúlio Vargas, 2005.

BARRÈRE-MAURISSON, M.A. La division familiale du travail - La vie en double. Paris: Presses Universitaires, 1992.

BERQUÓ, E. Arranjos familiares no Brasil: uma visão demográfica. In: SCHWARCZ, L.M. (Org.). História da vida privada no Brasil, São Paulo: Cia. das Letras, v.4, 2000.

BILAC, E. D. Convergências e divergências nas estruturas familiares no Brasil. Ciências Sociais Hoje. São Paulo: Anpocs, 1991.

BRUSCHINI, M. C.; LOMBARDI, M. R. A bipolaridade do trabalho feminino no Brasil: o emprego doméstico e as novas ocupações. São Paulo: FCC, 1999.

. Trabalho feminino no Brasil no final do século: ocupações tradicionais e novas conquistas. In: SEMINÁRIO TEMÁTICO INTERDICIPLINAR OS ESTUDOS DO TRABALHO: NOVAS PROBLEMÁTICAS,
Assim, o conjunto de informações apresentadas mostrou que os rearranjos familiares de inserção, articulados diante das transformações do mercado de trabalho, conseguiram reduzir o impacto negativo na renda familiar e, assim, atenuar o empobrecimento nas famílias da Região Metropolitana de São Paulo, muito embora não tenham conseguido impedir a queda do rendimento familiar.

NOVAS METODOLOGIAS E NOVAS ÁREAS DE PESQUISA. Campinas, Unicamp, nov., 2000

CASTEL, R. As metamorfoses da questão social. Uma crônica do salário. São Paulo: Vozes, 1998.

DEDECCA, C. S. O trabalho da mulher e sua contribuição para a renda da família. Programa Trabalho e Gênero no Brasil: formas, tempo e contribuição sócioeconômica. Unifem, 2005.

DEDECCA, C. S.; BALTAR, P. E. Precariedade ocupacional e relações de trabalho no Brasil nos anos 90. In: CONGRESSO DA ASSOCIAČÃO LATINO-AMERICANA DE SOCIOLOGIA, 21. São Paulo, 1997.

FERREIRA, M. I. C. Mobilidade inter e intrageracional de famílias trabalhadoras e moradoras de uma favela, num bairro de classe alta de São Paulo. In: ENCONTRO NACIONAL DE ESTUDOS POPULACIONAIS, 14, Caxambu. MG, 2004. Anais... Belo Horizonte, 2004.

GARCÍA, B.; ROJAS, O. Recent transformations in latin american families: a socio-demographic perspective. In: GENERAL CONFERENCE OF IUSSP, 24. Anais... 2001.

GARCÍA, B.; OLIVEIRA, O. La dinâmica familiar en la ciudad de México y Monterrey. CEDDU y CES, El Colegio de México, jul., 2000.

GOLDANI, A. M. A família brasileira em transição: evolução e perspectivas futuras. Taller de Trabajo-Familia, Desarrollo y 
Dinamica de Población en America Latina y el Caribe. Santiago, Chile, 1991.

GONZÁLEZ DE LA ROCHA, M. The erosion of a survival model: urban household responses to persistent poverty. In: WORKSHOP GENDER, POVERTY AND WELLBEING: INDICATORS AND STRATEGIES. UNRISD, UNDP, CDS. Trivandrum, Kerala, november, 1997.

La reciprocidad amenazada: un costo mas de la pobreza urbana. Revista Latinoamericana de Estudios del Trabajo, v.5, n.9, 1999.

HIRATA, H.; HUMPHEY, J. Estruturas familiares e sistema produtivo: famílias operárias na crise. Tempo Social - Revista de Sociologia da USP, São Paulo, v.4, n. 1 e 2, p. 111-131, 1994.

Nova divisão sexual do trabalho? Um olhar voltado para a empresa e a sociedade. São Paulo: Boitempo, 2002.

HIRATA, H.; KERGOAT, D. A divisão sexual do trabalho revisitada. In: MARUANI, M.; HIRATA, $H$. (Orgs.). As novas fronteiras da desigualdade: homens e mulheres no mercado de trabalho. São Paulo: Editora Senac, 2003.

HOFFMANN, M.; MENDONÇA, S. O mercado de trabalho na região metropolitana de São Paulo. Estudos Avançados, São Paulo: Editora USP, v. 17, n. 47, p. 2142, 2003.

JATOBÁ, J. A família na força de trabaIho: Brasil metropolitano - 1978-1986. In: ENCONTRO NACIONAL DE ESTUDOS POPULACIONAIS, 7, Caxambu. MG, 1990. Anais... Belo Horizonte, 1990.

LANGEVIN, A. La famile en recherche. Configurations familiales et vie domestique, v.30, p. 205-232, 2001 (Cahiers du Genre).

LAUTIER, B. La famile. Un amortisseur à la crise? Politis. La Revue, v.8, p. 25-30, 19941995.

LEONE, E. T. Renda familiar e trabalho da mulher na Região Metropolitana de São Paulo nos anos 80 e 90. In: ROCHA, M. I. B.
Trabalho e gênero: mudanças, permanências e desafios. São Paulo: Editora 34, 2000.

LEONE, E. T.; HOFFMANN, R. Participação da mulher no mercado de trabalho e desigualdade de renda domiciliar per capita no Brasil: 1981-2002. Nova Economia, Revista do Departamento de Ciências Econômicas da UFMG, v. 14, n 2, 2004.

MENDES, M. A. Mulheres chefes de família em 'áreas ZEIS': gênero, poder e trabalho. Tese de Doutorado. Recife: Centro de Filosofia e Ciências Humanas /UFPE, 2005.

MONTALI, L. Família e trabalho na conjuntura recessiva: crise econômica e mudança na divisão sexual do trabalho. Tese de Doutorado. São Paulo: Departamento de Sociologia /USP, 1995.

Família e trabalho na reestruturação produtiva: ausência de políticas de emprego e deterioração nas condições de vida. Revista Brasileira de Ciências Sociais, n. 42, Anpocs, 2000.

Família e trabalho: principais tendências no período 1985 a 2000. Crise, reestruturação produtiva e mudança na relação família-trabalho. Campinas: Nepp/ Unicamp, 2002. (Relatório final apresentado ao $\mathrm{CNPq}$ ).

Arranjos familiares e arranjos de inserção no mercado de trabalho nos anos 90. In: UNICEF/UNIVERSIDAD DE LA REPUBLICA. Nuevas formas de familiaperspectivas nacionales e internacionales. Montevideu: Unicef/Unversidade de la Republica, 2003a, p. 230-270.

Relação família-trabalho: reestruturação produtiva e desemprego. Revista São Paulo em Perspectiva, São Paulo, v. 17, 2003b.

MONTALI, L.; LOPES, G. Relações familiares e trabalho feminino na Região Metropolitana de São Paulo na década de 90. Caderno CRH, v.38, n.1, 2003.

Rearranjos familiares de inserção, precarização do trabalho e empobrecimento. Revista Brasileira de Estudos de População, v. 21, n 2 , 2004. 
NASCIMENTO, P. F. G. Não-provedores: desemprego e alcoolismo masculino em comunidades de baixa renda. In: SEMINÁRIO AS FAMÍLIAS E AS POLÍTICAS PÚBLICAS NO BRASIL. Belo Horizonte, nov. 2005.

OLIVEIRA, Z. L. C. A provisão da família e a pobreza: o caso de Belo Horizonte. In: SEMINÁRIO AS FAMÍLIAS E AS POLÍTICAS PÚBLICAS NO BRASIL. Belo Horizonte, nov. de 2005

POCHMANN, M. Inserção ocupacional e o emprego dos jovens. Coleção ABET - Mer- cado de trabalho. São Paulo, Abet, v.6, 1998.

SEADE/DIEESE. Pesquisa de Emprego e Desemprego. São Paulo. Disponível em: $<$ http://www.seade.gov.br>.

O mercado de trabalho feminino na Região Metropolitana de São Paulo em 2003. Boletim Mulher e Trabalho. Disponível em: <http://www.seade.gov.br>.

SEGNINI, L. R. P. Mulheres, mães e desempregadas: contradições de uma condição social. Anpocs, 2004.

\section{Abstract \\ Providers and co-providers: wives and female heads of families in unstable employment conditions and unemployment}

This article is based on two different sets of data. On the one hand, there are the changes in the labor market that have taken place as of the 1990s, which redefined the pattern of absorption of the labor force. On the other hand are the related changes in family arrangements regarding the work of their members, as well as changes in the role of women in the family and in society. The focus here is the character of the profiles of participation of wives and female heads of families who are providers or co-providers in their nuclear families. There has been increasing growth of the importance of the participation of these woman in the labor market, under unstable labor relationships and unemployment. At the same time, they have been taking on more significant roles in the composition of family income.

Although they often hold down unstable jobs, in comparison with other members of their families, only wives and female heads of families showed increased participation and occupation between 1990 and 2003. Especially important is the segment of working wives, half of whom under unstable or informal labor relationships, who show less reduction in the proportion of non-unstable relationships during this period.

The occupational profiles of members of the family groups in which these women participate are analyzed, and the families of wives and female heads of families who work and do not work were compared. The contribution of these women to the incomes of their nuclear families has softened the fall in income of their households and clearly attenuated the increasing impoverishment in the São Paulo Metropolitan Region.

Key words: Family rearrangements of participation in labor. Instability of labor. Unemployment.

Recebido para publicação em 04/09/2006. Aceito para publicação em 06/11/2006. 
